\title{
Dönüşümcü ve Etkileşimci Liderlik İle Örgütsel Özdeşleşme Arasındaki İlişki: Bir Meta-Analiz Çalıșması
}

\author{
Seval AKSOY KÜRÜ \\ Gebze Teknik Üniversitesi \\ drsevalaksoykuru@gmail.com \\ ORCID ID: 0000-0003-1370-0287
}

\begin{tabular}{lrr} 
Araştırma Makalesi & DOI: $10.31592 /$ aeusbed.735373 \\
\hline Geliş Tarihi: 10.05 .2021 & Revize Tarihi: 27.07 .2021 & Kabul Tarihi: 22.07 .2021
\end{tabular}

\section{Atuf Bilgisi}

Aksoy Kürü, S. (2021). Dönüşümcü ve etkileşimci liderlik ile örgütsel özdeşleşme arasındaki ilişki: Bir metaanaliz çalışması. Ahi Evran Üniversitesi Sosyal Bilimler Enstitüsü Dergisi, 7(2), 678-697.

\section{ÖZ}

Bu çalışmanın temel amacı, ulusal yazında dönüşümcü ve etkişleşimci liderlik ile örgütsel özdeşleşme arasındaki ilişkiyi inceleyen bireysel çalışmaların etki büyüklüğünü meta-analiz yöntemiyle belirlemektir. Bu amaçla, Yükseköğretim Kurulu (YÖK) Ulusal Tez Merkezi, Ulusal Akademik A ̆̆ ve Bilgi Merkezi (Ulakbim), Dergipark ve çeşitli uluslarararası veri tabanlarında ve arama motorlarında belirlenen anahtar kelimelerle lisansüstü tezler ve makaleler taranmıştır. 17 bireysel çalışmadan [Dönüşümcü liderlik $(\mathrm{k}=11)$ ve etkileşimci liderlik ( $\mathrm{k}=6)$ ] elde edilen veriler $(\mathrm{n}=4798)$, Comprehensive Meta Analysis yazılım programında analiz edilmiştir. Elde edilen sonuçlara göre, dönüşümcü liderlik ile örgütsel özdeşleşme arasındaki ilişki için metaanalize dahil edilen 11 çalışmanın rastgele etki büyüklüğüne göre etki büyüklüğünün orta düzeyde $(\mathrm{EB}=0.386$, $\mathrm{p}<0.05)$ olduğu anlaşılmaktadır. Etkileşimci liderlik ile örgütsel özdeşleşme arasındaki ilişki için meta-analize dahil edilen 6 çalıșmanın rastgele etki büyüklüğüne göre etki büyüklüğünün orta düzeyde $(\mathrm{EB}=0.347, \mathrm{p}<0.05)$ olduğu anlaşılmaktadır. Yayın türü, yayın yılı, örgütsel özdeşleşme ölçekleri, dönüşümcü liderlik, etkişleşimci liderlik ölçekleri ve çalışmaların yapıldığı sektör bakımından farklılık olup olmadığına bakmak için moderatör analizleri de yapılmıştır. Ancak, desteklenen bir moderatör etki sonucuna ulaşılmamıştır.

Anahtar Kelimeler: Dönüşümcü liderlik, etkileşimci liderlik, örgütsel özdeşleşme, meta-analiz.

\section{The Relationship between Transformational and Interactive Leadership and Organizational Identification in National Literature: A Meta-Analysis}

\begin{abstract}
The main purpose of this study is to determine the total effect of individual studies examining the relationship between transformative and interactive leadership and organizational identification in the national literature by meta-analysis method. For this purpose, postgraduate theses and articles with keywords determined in Council of Higher Education (CoHE) National Thesis Center, Turkish Academic Network and Information Center (Ulakbim), Dergipark and in various international databases were scanned. Data from 17 individual studies [transformative leadership $(\mathrm{k}=11)$ and interactive leadership $(\mathrm{k}=6)$ ] $(\mathrm{n}=4798)$ were analyzed in the Comprehensive Meta Analysis (CMA) software program. According to the results obtained, it is understood that the effect size is medium level $(\mathrm{ES}=0.386, \mathrm{p}<0.005)$ according to the random effect size of 11 studies included in the meta-analysis for the relationship between transformative leadership and organizational identification. It is understood that the effect size is medium level $(E S=0.347, \mathrm{p}<0.05)$ according to the random effect size of the 6 studies included in the meta-analysis for the relation between interactive leadership and organizational identification. Moderator analyzes were also carried out to see if there are differences in terms of publication type, publication year, organizational identification scales, transformative leadership, interactive leadership scales and the sector in which the studies are conducted. However, a supported moderator effect result has not been reached.
\end{abstract}

Keywords: Transformational leadership, interactive leadership, organizational identification, meta-analysis.

\section{Giriş}

Örgütlerin en değerli sermayesi olan çalışanların örgütlerine besledikleri duygular ve bunların olumlu birer davranışa dönüşmesi çok önemlidir. Günümüzde örgütler, iş yaşamında yoğun rekabet koşulları içinde olmalarından dolayı zaman zaman düşük iş tatmini yaşayan çalışanlarla ve devamında da yüksek iş devir oranlarıyla karşı karşıye kalmaktadırlar. Örgütünü yalnızca maddi bir kaynak olarak görmekten çok daha fazlasına yani duygusal ve bilişsel anlamda sahiplenmeye erişen çalışanlar örgütler için olmazsa olmazdır. Ben kimim sorusuyla başlayıp biz kimiz sorusuna evrilen ve Sosyal Kimlik Kuramından (Tajfel, 1978; Tajfel ve Turner, 1986) kök alan örgütsel özdeşleşme, çalışanın örgütüne kalben aidiyetini temsil etmektedir. Bu denli kıymetli bir adiyetin oluşmasında da çalışanlar için birer 
rol model gerekmektedir. Dönüşümcü liderlik ve etkileşimci liderlik de bahsi geçen bu rol model için önemli birer örnektir. Örgütün içinde yer alan grupların özelliklerini ve amaçlarını çalışanlara anlatma ve benimsetmede liderin rolü yadsınamaz. Dönüşümcü liderler de bu rolü yerine getirmede oldukça etkindirler (Podsakoff, Mackanzie, Moorman ve Fetter, 1990). Bu sayede de çalışan, örgütünü tanıyabilecek ve örgütüyle özdeşim kurması kolaylaşacaktır. Etkileşimci liderlikte ise çalışanlarla yakın bir etkileşim ve açık bir iletişim söz konusudur (Coad ve Berry, 1998). Ayrıca, çalışanların örgütün amaçlarına erişmesinde çabaları nazarında ödüllendirmeleri görülmektedir. Bu da örgütün amaçlarını içselleştirmek ve uzun vadede de örgütü içselleştirerek özdeşim yaşamada kilit bir noktayı temsil etmektedir.

Ulusal yazına bakıldığında dönüşümcü liderlik ve etkileşimci liderliğin örgütsel özdeşleşme ile ilişkisini konu almış olan bireysel çalışma sayısının oldukça fazla olduğu görülmektedir. Çalışanların örgütleriyle özdeşleşmelerinde liderlik türlerinden en yaygın olarak kullanılan bu iki türün etkisini, bireysel çalışmaların etki büyüklüklerinin çelişkili sonuçlarının ortadan kaldırılması ve bu bireysel çalışmaların genel etki büyüklüğü değerini ifade eden bir meta-analiz çalışması uluslararası yazında mevcutken Türkiye örgütsel davranış yazınında bu iki liderlik türünün örgütsel özdeşleşmeyle ilişkisini ele almış bir meta-analiz çalışmasına rastlanmamaktadır. Bu nedenle de dönüşümcü liderlik ve etkileşimci liderlik ile örgütsel özdeşleşme arasındaki ilişkinin ve etkinin tam olarak hangi seviyede olduğunu nicel olarak ortaya koyabilen bir meta-analiz çalışmasının olmayışı bu çalışmanın temel motivasyonunu oluşturmaktadır. Bu çalışmanın amacı, Türkçe yazında bireysel araştırmacılar tarafindan neredeyse hiç tercih edilemeyen meta-analiz yöntemini kullanarak Türkiye örneklemini kullanmış olan araştırmalarda; dönüşümcü liderlik ve etkileşimci liderlik ile örgütsel özdeşleşme ilişkisini inceleyen bireysel çalışmaların etki büyüklüğü değerlerine ulaşabilmektir. Bunun yanı sıra alt amaçlar ise, yayın yanlılığı, yayın yılı ve türü, kullanılan ölçeklere bağlı olarak oluşabilecek olası moderatör etkileri de test edebilmektir. Bu sayede, bu üç kavram arasındaki ilişkiye yönelen çok sayıdaki bireysel çalışmanın sonuçlarının birleştirilerek özetlenmesiyle büyük resmi ortaya koyabilmek mümkün olacaktır. Türkiye yönetim ve örgütsel davranış alanına kıymetli bir katkı sağlaması beklenen bu çalışmayla hem örgütler için liderliğin ve bu sayede de örgütsel özdeşleşmenin önemi anlaşılır kılınacak hem de gelecekteki araştırmacılar için nitelikli bir rehber hazırlanmış olacaktır.

\section{Dönüşümcü Liderlik}

Temelleri Downton (1973) tarafından “İsyan Liderliği” başlıklı kitapla ortaya atılan dönüşümcü liderlik, Burns'un 1978'de özellikle siyasi liderler üzerinde yapmış olduğu çalışmaların bir ürünü olan "Liderlik" isimli eseriyle daha da belirgin hale gelmiştir. Tarihsel süreçte özellikle de 1990'larda artan ilgiyle örgüt yöneticileri tarafından tercih edilir ve uygulanır hale gelmiştir. İlk başlarda karizmatik liderliğin özellikleri üzerinde duruluyor gibi anılsa da temelde etkili liderlik kuramlarının harmanlamasıyla bir liderin sahip olması gereken kişilik özelliklerini barındırdığı anlaşılmaktadır (Dubrin, 2010). Dönüşümcü liderlik, manevi anlamda da etkileyici olmaktadır. Sahip olduğu özellikler (güvenilir ve etkileyici olma, vb.) sayesinde çalışanları etkileyerek onlar için bir vizyon tayin ederek onların yeteneklerinin öne çıkmasına ve kendilerini tanımalarına yardımcı olmaktadır (Bottery, 2001). Böylece, dönüşümcü liderler, örgütün içinde bulunduğu değişen ve yoğun rekabet içeren çevre şartlarına uyum sağlayabilmesine yardımcı olmaktadır. Ayrıca, çalışanların da değer yargılarını, inançlarını ve tutumlarını örgütünkilerle bağdaştırarak örgüte karşı duygusal bir yakınlık oluşturmada etkilidir. Dönüşümcü liderler, örgütün amaç ve hedeflerini kaliteli iş çıktılarına ulaşmak için çalışanların sahip olduğu yeteneklerin yanı sıra potansiyel yeteneklerini de ortaya koymalarında ön ayak olmaktadır. Bu sayede de çalışanların performanslarını birkaç adım daha ileri seviyeye çekebilmeyi arzulayan oldukça etkin bir liderlik türüdür demek mümkün olmaktadır (Nielsen ve Cleal, 2011).

\section{Etkileșimci Liderlik}

Etkileşimci liderlik de tıpkı diğer liderlik türlerinde olduğu gibi çalışanların neyi ne zaman ve ne şekilde yapması hususunda rehberlik etmeyi anlatır. Etkileşimci liderlik, Burns'un (1978) ifadesiyle, hedefleri çalışanlarla etkileşim içinde veya bağımsız bir şekilde gerçekleştirmek üzere; çatışma ve rekabet ortamında bir takım güdü, değer, ekonomik ve politik kaynakları olan kişileri karşılıklı olarak 
harekete geçirme sürecinin tamamıdır. Bass'ın (1999) anlatımıyla etkileşimci liderlik, çalışanlarla lider arasında bazı etkileşimler vardır ve bu etkileşimler, liderin çalışanlarının işlerinden elde edecekeleri kazanımlarının neler olduğunu fark ederek onlar için ödül belirlemesini içeren bir davranışı tanımlar. Ne elde etmek istediklerini fark etmesi ve buna karşıllk izleyicileri için ödüller oluşturmasını içerir (Macit, 2003). Odumeru ve Ifeanyi'nin (1996) da belirttiği gibi etkileşimci liderliğin örgütteki varlığ1 halinde, çalışanlara görev tanımlarının ve rollerinin açıklanmasıyla onların daha hızlı organize olması ve yüksek motivasyonla kaliteli çıktılar elde etmesi görülmektedir (Bolat, 2011). Nitekim, etkileşimci liderin çalışanlara çabalarının karşılığında belli ölçütler çerçevesinde belirlenmiş olan bazı taktimleri vardır. Bu sayede çalışanlar için yalnızca örgüt nezninde bir kazanım değil bireysel bir kazanım da oluşmaktadır ve çalışan tarafından liderin otoritesini kabullenme hızlı gerçekleşmektedir (Gomes, 2014). Tüm bu ifadelerin de anlatmaya çalıştığı üzere, etkileşimci liderlik, açık iletişimin ve etkileşimin yüksek yaşandığı bir liderlik türüdür.

\section{Örgütsel Özdeşleşme}

Hiçbir canlının uzun süre kendi başına yaşayamayacağı ve hatta zamanla bir grubun içinde olma arzusu güdeceğini öne süren Sosyal Kimlik Kuramı (Tajfel, 1978; Tajfel ve Turner, 1986), bireylerin birer sosyal kimlik kazanmak yönündeki istediklerini vurgulamaktadır. Temelleri bu kurama dayanan örgütsel özdeşleşme, çalışan tarafindan örgütün başarılı ve/veya başarısız olma halini de benimseyip kabullenerek örgüte yönelik aidiyet hissetmesi, birlik içinde olmasını ifade etmektedir (Ashforth ve Mael, 1989). Temel vurgusu örgütsel aidiyet olan örgütsel özdeşleşme, çalışanın yalnızca duygusal değil aynı zamanda bilişsel olarak da bağlılık ve adanma içinde olduğunu ifade etmektedir. Patchen'e (1970) göre örgütüne yönelik dayanışma, birlik içinde olma, örgüte destek olma ve örgütün üyeleriyle paylaşılan ortak değer ve özellikler bütünü olan örgütsel özdeşleşme, çalışanın kendini tanımlarken örgütün nitelikleriyle uyumlaştırarak bilişsel bir bağ içinde olmasıdır (Dutton, Dukerich ve Harquail, 1994). Yoğun içselleştirmenin yaşandığı örgütsel özdeşleşmede çalışanın örgütünün başarı ve başarısızlıklarını tıpkı kendi başarısı ve başarısızlığı gibi benimsemesi görülmektedir (Mael ve Ashforth, 1992).

\section{Kavramlar Arasındaki İlişkiler ve Alt Problemler}

Etkileşimci liderliğin hâkim olduğu bir örgütte çalışanların rollerinin açıklığı ve bireysel hedeflerin belirlenmesiyle kendini güven ve hatta otorite tarafindan oluşturulan bir çember içinde koruma altında hissetmektedir. Bu da tıpkı bir bireyin aile içindeki sorumluluğunun ne olduğunun bilinci ve farkındalığıyla yapması gerekenlerin belirlenmesine benzemektedir. Böylece çalışan, kendisini adeta örgütün olmazsa olmaz bir unsuru olarak kabul ederek sorumluluklarına sıkı sıkıya bağlı hareket edip örgütünün başarısı için çaba sarf etmek üzere uğraşacaktır. Etkileşimci liderliğin çalışanların örgütün misyonunu ve vizyonunu kendi çalışma alanları kapsamında algılamasına imkân vermesi, amaçlara ulaşmada ve bu sayede de örgütsel özdeşleşme yaşamalarında önemli bir etkendir (Jung ve Avolio, 1999). Çalışanlarla dönüşümcü liderlik arasındaki ilişkiye bakıldığında, etkileşimci liderlikteki gibi çalışanların statülerine bakılmaksızın onların görüşlerine önem verildiği ve onların teşvik edildiği görülmektedir (Coad ve Berry, 1998). Benzer şekilde Podsakoff vd. (1990) göre, çalışanların dahil oldukları grubun amaçlarını kabul etmeleri dönüşümcü liderliğin davranış kalıbının bir yansımasıdır ve bu sayede de örgütsel özdeşleşme için sağlam bir zemin hazırlanmaktadır. Epitropaki ve Martin'e (2005) göre ise dönüşümcü liderlik ve etkişimci liderlik, örgütsel özdeşleşmeye pozitif yönde etki etmektedir. Yaptıkları çalışmada dönüşümcü liderliğin etkileşimci liderliğe nazaran örgütsel özdeşleşme üzerinde daha yüksek etki oluşturduğunu bulgulamışlardır. Yazında bahse konu olan değişkenlerin ilişkisini ele alan bir meta-analiz çalışmasına rastlanmamıştır. Türkiye örneklemiyle yapıllmış ve değişkenler arasındaki ilişkiyi daha önceden ele almış olan bireysel görgül çalışmaların sonuçlarına bakıldığında ise tamamının pozitif yönde anlamlı olduğu görülmektedir. Ancak beklenenin aksine elde edilen her bulgunun yüksek düzeyde olmadığı da açıktır. Dönüşümcü liderlik ile olan ilişki için, örneğin; İşcan'ın (2006) Erzurum'da küçük ve orta büyüklükteki işletmelerinin (KOBİ) çalışanları üzerinde yaptığı araştırmasında dönüşümcü liderlik ve örgütsel özdeşleşme arasındaki ilişki 0.310 olarak bulunurken; Özsöylemez'in (2009) İstanbul, İzmir ve Bodrum'da görev yapan Bağımsız Denetim ve Danışmanlık ile bankacılık sektörlerinde faaliyet gösteren firmalarda orta kademe çalışanlarıyla gerçekleştirdiği 
çalışmasında 0.589 olarak belirtilmiştir. Güngör (2010) Türk Silahlı Kuvvetleri (TSK) bünyesindeki personellerle yürüttüğü çalışmasında dönüşümcü liderlik ve örgütsel özdeşleşme arasındaki ilişkiyi 0.250 olarak tespit ederken; Eren ve Çakır-Titizoğlu'nun (2014) Bolu'da faaliyet gösteren orta ve büyük ölçekli beş farklı üretim işletmesindeki mavi ve beyaz yakalı çalışanları örneklem aldığı çalışmada bu ilişkinin 0.398 olduğu görülmektedir. Etkileşimci liderlik ile olan ilişki ise; örneğin, Çeri-Booms'un (2009) kurumsal yönetim ilkelerini benimsediği kabul edilen Türk işletmelerindeki çalışanlarla gerçekleştirdiği çalışmasında 0.250 olarak belirtilmiştir. Erdoğan-Morçin ve Morçin'in (2013) Doğu Akdeniz bölgesinde yer alan Adana'da faaliyet gösteren A grubu seyahat acentelerindeki çalışanlar üzerindeki çalışmasında etkileşimci liderlik ve örgütsel özdeşleşme arasındaki ilişki 0.365 olarak belirlenmiştir. Erdoğan-Morçin ve Çarıkçı'nın (2016) Antalya'daki beş yıldızlı otel çalışanlarını örneklem olarak seçtiği çalışmada ise bu ilişki düzeyi 0.498 olarak tespit edilmiştir.

Örgütsel özdeşleşme ile dönüşümcü liderlik ve etkileşimci liderlik arasındaki ilişkileri incelemiş olan bireysel çalışmaların nedensellik anlamında tartışmalı ve/veya çelişkili sonuçlar içerdiği söylemek mümkün değildir. Bu durumda ise çalışanların liderlik algılarıyla örgütleriyle özdeşleşmeleri arasında ilişki düzeyleri farklılık göstermiş olsa da pozitif yönde anlamlı bir ilişki olması beklenmektedir. Fakat, liderlerin her türlü çaba, rehberlik ve teşvik etme davranışlarına rağmen çalışanların örgütsel değer ve amaçlarla uyumlaşmıyor olması da olasıdır. Buna etki edecek olan doğrudan gözlemlenebilir ve/veya gözlemlenemez durumda olan birçok unsur (kişilik, örgtü kültürü, sosyo-kültürel çevre, algılama vb.) olacağı da ihtimal dahilindedir. Bireysel çalışmaların yürütüldüğü çevredeki kültürün etkisi de değerlendirilerek hareket etmek daha rasyonel sonuç verecektir ki Türkiye'nin baskın olarak kolektif kültür özelliklerine sahip olduğu da bilinmektedir. Daha önceden yapılmış olan bireysel araştırmaların sonuçlarıyla kavramlar arasındaki ilişkiyi ortaya koymaya çalışan kuramsal temele bağlı kalınarak yapılan bu meta-analiz çalışmasında test edilmek üzere belirlenen alt problemler aşağıda sıralanmıştır.

- Dönüşümcü liderlik ile örgütsel özdeşleşme arasında pozitif yönde anlamlı bir ilişki var mıdır?

- Yayın yıl1, yayın türü, dönüşümcü liderlik ölçekleri, örgütsel özdeşleşme ölçekleri ve sektör dönüşümcü liderlik ile örgütsel özdeşleşme arasındaki pozitif ilişkide moderatör müdür?

- Etkileşimci liderlik ile örgütsel özdeşleşme arasında pozitif yönde anlamlı bir ilişki var mıdır?

- Yayın yıl1, yayın türü, dönüşümcü liderlik ölçekleri, örgütsel özdeşleşme ölçekleri ve sektör dönüşümcü liderlik ile örgütsel özdeşleşme arasındaki pozitif ilişkide moderatör müdür?

\section{Yöntem}

Araştırmanın bu bölümünde dönüşümcü ve etkileşimci liderlik ile örgütsel özdeşleşme arasındaki ilişki üzerine yapılan meta-analiz çalışması için araştırma deseni, evren ve örneklem, veri toplama araçları, akış diyagramı, araştırmanın etiği ve verilerin analizi hakkında bilgi verilmektedir.

\section{Araştırma Deseni}

Hunter ve Schmidt'in (2004) ifadesiyle; meta-analiz; gözden geçirme ve tekrar incelemeye tabi tutma çalışmalarına nazaran, ele alınan değişkenler arasındaki ilişkileri mümkün oldukça gerçeğe en yakın haliyle vererek bireysel çalışmalardaki sonuçları nicel olarak bir araya getirip özetlemeye imkân vermektedir. Bahsi geçen bu gücü faydaya dönüştürebilmek amacıyla dönüşümcü liderlik ve etkileşimci liderlik ile örgütsel özdeşleşme arasındaki ilişkileri ele alan, şimdiye kadar birikmiş birçok bireysel çalışmanın $(\mathrm{k}=17)$ sonucunu meta-analiz yöntemiyle birleştirerek, bireysel çalışmaların oluşturduğu toplam değeri tespit edilmek amaçlanmaktadır.

\section{Evren ve Örneklem}

Araştırmanın evren ve örneklemini Türkiye örneklimi ele almış olan ve dönüşümcü liderlik ve etkileşimci liderlik ile örgütsel özdeşleşme arasındaki ilişkileri değerlendiren bireysel çalışmalar oluşturmaktadır. Günümüze kadar dönüşümcü liderlik ve etkileşimci liderliğin örgütsel özdeşleşmeyle ilişkisini konu alan bir meta-analiz çalışması olmadığı için 2019 yılı aralık ayı dâhil olmak üzere ulusal yazındaki tüm çalışmalar ele alınmıştır. 


\section{Veri Toplama Araçları}

Yükseköğretim Kurulu (YÖK) Ulusal Tez Merkezi, Ulusal Akademik Ağ ve Bilgi Merkezi (Ulakbim), Dergipark, ERIC, DOAJ, PsycINFO, Sage Journals Online, Science Direct, Springer Link, Taylor and Francis Online Journals, Wiley Online Library veri tabanları kullanılmıştır. Ayrıca, internet arama motorlarında (Google Scholar, Yandex ve Google) da tarama yapılmışıı. Tarama yapılırken örgütsel özdeşleşme, örgütle özdeşleşme, örgütsel özdeşim, örgütle özdeşim, örgütsel kimlik, örgütsel kimliklenme, organizational identification, organizational idendity, oi, öö, örg. özd., dönüştürücü liderlik, dönüşümcü liderlik, dönüşümsel liderlik, etkileşimci liderlik, etkileşimsel liderlik, transformational leadership ve interactive leadership anahtar kelimeleri kullanılmıştır. Ulaşılan çalışmalar ayrıntılı olarak incelenmiştir. Uygun olduğu düşünülen araştırmaların özetleri okunarak meta-analize dahil edilme ölçütlerini taşıyanlar ve potansiyel nitelikte olanlarla birlikte meta-analiz kodlama formuna aktarılmıştır. Yayınlanmamış çalışmalara ulaşılmasında ise Yükseköğretim Kurulu (YÖK) tez tarama sisteminde henüz erişimine izin verilmemiş olan doktora tez çalışmalarını metaanalize dâhil edebilmek amacıyla yazarlara e-posta metni gönderilerek ilgili teze erişim talep edilmiştir. Yazardan cevap alınmak üzere 15 gün beklemenin ardından enstitülerine ve tez danışmanlarına ulaşım sağlanarak tüm doktora tezlerine erişilmiştir. Yüksek lisans tezleri içinse sosyal medya aracı olan Linkedin ve tıpkı doktora tezlerine erişebilmek için izlenen alternatif adımlardan biri olan tez danışmanı ve enstitüleri vasıtasıyla iletişim kurulması amaçlanmıştır. Doktora tez sahiplerine gönderilen e-posta metni yükssek lisans tezlerinin erişimi için uyarlanarak taraflara iletilmiştir. Böylece hem doktora hem yüksek lisans tezlerinin tamamına erişim sağlanmıştır. Bu çalışmaların ve konu özelindeki makalelerin analize dahil edilmesinde ise aşağıda da sıralandığı üzere bazı kriterler gözetilmiştir.

- Meta-analize dahil edilecek olan bireysel çalışmaların örgütsel özdeşleşme ve dönüşümcü liderlik ve/veya etkileşimci liderlik arasındaki ilişkiyi ele almış olması,

- Örgütsel özdeşleşme ve dönüşümcü liderlik ve/veya etkileşimci liderlik arasındaki ilişkiyi ele almış olan bireysel çalışmanın Türkiye örneklemini incelemiş olmaları,

- Türkiye örneklemini incelemiş olan bireysel çalışmaların bu ilişkiyi bir örgütte fiilen çalışmakta olan bireyler üzerinde ele almış olmaları,

- Konu özelinde yapılmış olan bireysel çalışmaların mutlaka görgül çalışmalar olması,

- Doğru anlaşılması ve doğru değerlendirme yapılabilmesi için örgütsel özdeşleşme ve dönüşümcü liderlik ve/veya etkileşimci liderlik arasındaki ilişkiyi ele almış olan bireysel çalışmaların Türkçe ve/veya İngilizce dillerinde hazırlanmış olmaları,

- Örgütsel özdeşleşme ve dönüşümcü liderlik ve/veya etkileşimci liderlik arasındaki ilişkiyi ele almış olan bireysel çalışmaların her birinin titiz ve objektif bir hakem değerlendirmesinden geçmiş olmaları,

- Bu bireysel çalışmaların ele alınan bu ilişkiyi değerlendirdiğine ilişkin olarak ortaya koyduğu bulgu ve sonuçlarda korelasyon katsayısı veya korelasyon katsayısının hesaplanmasına yardımcı olan değerlere (t-testi ve $\mathrm{F}$ testi) yer vermesidir.

Meta-analiz kapsamına alınmamaya neden olan kriterler ise aşağıdaki gibidir.

- Lisansüstü çalışmalar ve makaleler dışındaki bildiri metinlerinin nitelikli ve objektif bir hakem değerlendirmesine tabi olmamaları nedeniyle meta-analiz çalışmasına dahil edilmemesi,

Bireysel araştırmacıların aynı örneklemi kullanarak biden fazla çalışma yapmış olması durumunda her ne kadar farklı yıllarda yapılmış olsalar dahi yapılmış olan bu bireysel çalışmalardan yalnızca bir tanesinin meta-analize dahil edilmesidir. Tüm bu kriterler ve izlenen adımları içeren sistematik derleme ve meta-analiz için kullanılan PRISMA (Preferred Reporting Items for Systematic review and Meta-Analysis Protocols) akış şemasının Türkçe versiyonuna Tablo 1'de yer verilmiştir (Aşı1k ve Özen, 2019). 
Tablo 1

Dönüşümcü Liderlik ve Etkileşimci Liderlik İle Örgütsel Özdeşleşme Arasındaki İlişkiye Ait Alanyazın Taraması ve Erişilen Bireysel Çalı̧̧maların Meta-Analize Dahil Edilme Sürecini Gösteren Akış Diyagramı

Veri tabanları; Yüksek Öğretim Kurumu Ulusal Tez Merkezi ulusal veri tabanları (Ulusal Akademik

$\begin{array}{ll}:= & \text { Ağ ve Bilgi Merkezi ULAKBIM-Sosyal Bilimler Veri Taban1), Dergipark, ERIC, DOAJ, PsycINFO, } \\ \text { : } & \text { Sage Journals Online, Science Direct, Springer Link, Taylor and Francis Online Journals, Wiley } \\ \text { Online Library. İnternet arama motorları; Google, Google Scholar ve Yandex }\end{array}$ Online Library. İnternet arama motorlar1; Google, Google Scholar ve Yandex

Eș kopyalar elendikten sonra kalan bireysel çalışmalar $(\mathrm{k}=3132)$

\begin{tabular}{|c|c|}
\hline$\frac{\overline{0}}{\frac{0}{3}}$ & $\begin{array}{l}\text { Meta-analizine dahil edilecek bireysel çalış̧naların; } \\
\text { Dönüsümcü liderlik ve/veya etkileşimci liderlik ve örgütsel özdeşleşme arasındaki ilişkinin } \\
\text { araştırılmış olmasıdır. } \\
\text { Bireysel çalışmaların Türkiye örneklemini içeren çalışmalar olmasıdır. } \\
\text { Dönüşümcü liderlik ve/veya etkileşimci liderlik ve örgütsel özdeşleşme arasındaki ilişkinin görgül } \\
\text { olarak ölçülmedir. } \\
\text { Yapılan bireysel çalışmaların tam metin makale, yüksek lisans tezi ve doktora tezi olmasıdır. } \\
\text { Bireysel çalışmalarda korelasyon katsayılarının ya da korelasyon katsayısını hesaplamaya imkân } \\
\text { veren değerlerin (t-testi ve F testi) verilmiş olmasıdır. } \\
\text { Bireysel çalışmalardaki örneklemin bir örgütte fiilen çalışan bireylerden oluştuğunu ifade ediyor } \\
\text { olmasıdır. } \\
\text { Bireysel çalışmaların aynı örneklemi kullanarak farklı yıllarda yayın sunması halinde yalnızca bir } \\
\text { tanesinin kabul edilmesidir. }\end{array}$ \\
\hline & $\longrightarrow \quad \begin{array}{l}\text { Hariç tutulan özetler }(\mathrm{k}=1045) \\
(\mathrm{k}-\text { Dön. Lid. = 707) } \\
(\mathrm{k}-\text { Etk. Lid. }=538)\end{array}$ \\
\hline & 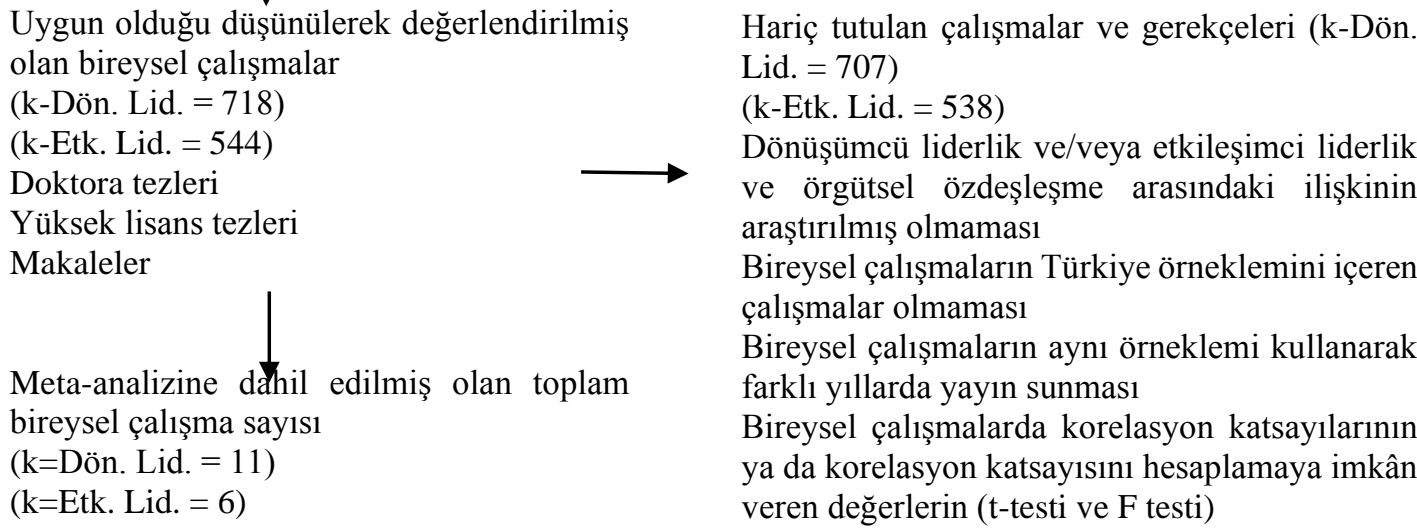 \\
\hline
\end{tabular}

Nihayetinde, araştırma kapsamında 19 bireysel çalışmaya ulaşılmıştır. Yapılan ayrıntılı incelemeyle 19 çalışmadan meta-analize dahil edilmenin temel kriteri olan korelasyon değeri ya da korelasyon değerinin belirtilmemiş olması halinde hesaplamaya yardımcı olan t-testi ve $\mathrm{F}$ testi sonuçlarını sunmuş olan 17 bireysel çalışma meta-analize dahil edilerek sonuçları değerlendirilmiştir.

\section{Verilerin Analizi}

Verilerin analizi için öncelikle kodlama işlemleri yapılmıştır. Dönüşümcü liderlik ve örgütsel özdeşleşme, etkileşimci liderlik ve örgütsel özdeşleşme arasındaki ilişkileri ele alan bireysel çalışmalar üzerinden meta-analiz yapmayı amaçlayan bu çalışmada Hunter ve Schmidt (2004) ve Card'ın (2012) çalışmalarında kullandıkları kodlama formları kullanılmıştır. Kodlama formları üç türde hazırlanmıştır. Birincisi, meta-analize dahil edilen çalışmanın tam adı, yazar(lar)1, yayın yılı, yayın türü ve örneklem sayısını, ikincisi, çalışmaların örneklemine ilişkin cinsiyet ve çalışmanın yapıldığı sektör bilgisini, 
üçüncüsü ise, çalışmalarda kullanılan ölçek bilgisi, ölçeklerin Cronbach alfa katsayıları, korelasyon katsayıları, ölçeklerin ortalama ve standart sapma değerini kapsamaktadır. Araştırmacının hazırlamış olduğu üçlü kodlama formalarına yapılan kodlamalarda formlarının gerektirdiği özellikleri içermeyen çalışma (Özsöylemez, 2009) analize dahil dışına alınmıştır. Dönüşümcü liderlik ve örgütsel özdeşleşme, etkileşimci liderlik ve örgütsel özdeşleşme arasındaki ilişkiyleri inceleyen bireysel çalışmaların analizlerinde Comprehensive Meta Analysis (CMA) paket programı kullanılmıştır. Çalışmada Cohen, Manion ve Morrison'un (2007) önermiş olduğu korelasyona ilişkin etki büyüklüğü eşik değerleri rehber alınmıştır. Dönüşümcü liderlik ve örgütsel özdeşleşme, etkileşimci liderlik ve örgütsel özdeşleşme arasındaki ilişkiyi inceleyen ve analize dahil edilmiş olan toplam 17 çalışmadaki toplam örneklem sayıları sırasıyla 2954 ve 1844 'tür. Dönüşümcü liderlik ve örgütsel özdeşleşme arasındaki ilişkiyi incelemiş olan bireysel çalışmalardaki örneklemin 1030'u kadınlardan; 1923'ü erkeklerden oluşurken; etkileşimci liderlik ve örgütsel özdeşleşme arasındaki ilişkiyi incelemiş olan bireysel çalışmalardaki örneklemin ise 557'si kadınlardan; 1286'sı erkeklerden oluşmaktadır. Çalışmalarda 2 kişilik örnekleme ilişkin herhangi bir bilgi yoktur.

Araştırmaya dahil edilen toplamda 17 bireysel çalışmadan elde korelasyon katsayıları ve örneklem büyüklüğü meta-analizde etki büyüklüklerini hesaplamada kullanılmıştır. Bireysel çalışmaların analizinde ilk önce homojenlik-heterojenlik testleri yapılmıştır. Test sonuçlarının kritik değeri aşmış olup olmamasına ve anlamlılık değerinin 0.05 'ten küçük olup olmamasına bakılarak uygun etki büyüklügü modeli (sabit veya rastgele) seçilmiştir. Elde edilen bulgular, ilişkiyi ele alan toplam çalışma sayısı (k), örneklem büyüklügü $(\mathrm{N})$, etki büyüklügü (nokta tahmini) (r), alt-üst limitler, Fisher's $\mathrm{z}$ değeri, Q değeri, serbestlik derecesi ile $\mathrm{p}$ değerine bakılarak değerlendirilip yorumlanmıştır. Metaanalize dahil edilmiş 17 bireysel çalışmada herhangi bir yayın yanlılı̆̆ amaciyla Begg ve Mazumdar'ın (1994) sıra korelasyon testi uygulanmıştır. Bu teste binaen, Kendall Tau katsayısında ulaşılan sonuçların istatistiksel olarak anlamlı olmaması halinde yayın yanlılı̆̆ının olmadığ1 söylenebilmektedir (Field ve Gillett, 2010). Bu teste binaen, elde edilen Kendall Tau katsayısına, bir başka analiz olan Egger regresyon analizi sonucunda elde edilen değere ve Rosenthal'in öne sürmüş olduğu değere göre de değerlendirmeler yapılmıştır. Ayrıca huni saçılım grafiklerinin yorumlarına da yer verilerek çalışmaların simetriği hakkında bilgi verilmeye çalışmıştır. Yayın yanlılığın dişında örgütsel özdeşleşme ile dönüşümcü liderlik ve/veya etkileşimci liderlik arasındaki ilişkiyi ele almış ve meta-analiz çalışmasına dahil edilmeye uygun görülmüş olan 17 bireysel çalışmanın yayın yılına ve türüne, çalışmanın yapılmış olduğu sektöre, çalışmalarda tercih edilmiş olan örgütsel özdeşleşme ve dönüşümcü liderlik ve/veya etkileşimci liderlik ölçeklerine bağlı olarak gözlemlenebilecek bir farklılığı yorumlayabilmek için moderatör etki analizleri yapılmıştır.

\section{Araștırma Etiği}

Yapılan bu çalışma bir meta-analiz çalışması olması nedeniyle etik kurul kararı gerektirmemektedir. Birincil veri toplanmamıştır. Araştırma verisi daha önce yapılmış olan çalışmaların sonuçlarından elde edilmiştir.

\section{Bulgular}

Dönüşümcü liderlik ve örgütsel özdeşleşme arasındaki ilişkiyi ele almış ve bu meta-analiz çalışmasına dahil edilen bireysel çalışmaların 11 tane $(\mathrm{k}=11)$ olduğu bilinmektedir. Çalışmalar (yüksek lisans tezi, doktora tezi ve makale) tarihsel olarak 2006-2019 yılları arasında yayımlanmışlardır. On bir bireysel çalışmanın ikisinin doktora tezi (Tez (D)), altısının yüksek lisans tezi (Tez (YL)) ve dokuzunun da makale olduğu bilinmektedir. Makale çalışmaları en az tek; en çok iki yazarlıdır. Örneklem sayılarına bakıldığında ise en küçük örneklem sayısının 147; en büyük örneklem sayısının ise 644 olduğu anlaşılmaktadır. Toplam örneklem sayısının 2954 olduğu bilgisine bağlı kalarak ortalama örneklem büyüklüğü ise, 269'dur. Etkileşimci liderlik ve örgütsel özdeşleşme arasındaki ilişkiyi ele almış ve bu meta-analiz çalışmasına dahil edilen bireysel çalışmaların ise altı tane $(\mathrm{k}=6)$ olduğunu anlaşılmaktadır. $\mathrm{Bu}$ çalışmalar (doktora tezi ve makale), tarihsel olarak 2006-2016 yılları arasında yayımlanmışlardır. Altı bireysel çalışmanın ikisinin doktora tezi (Tez (D)) ve dördünün de makale olduğu bilinmektedir. Makale çalışmaları en az tek; en çok iki yazarlıdır. Örneklem sayılarına bakıldığında ise en küçük 
örneklem sayısının 153; en büyük örneklem sayısının ise 644 olduğu anlaş1lmaktadır. Toplam örneklem sayısının 1844 olduğu bilgisine bağlı kalarak ortalama örneklem büyüklüğü ise, 307'dir.

\section{Dönüşümcü Liderlik ve Örgütsel Özdeşleşme Arasındaki İlişkide Etki Büyüklüğü Bulguları}

Dönüşümcü liderlik ile örgütsel özdeşleşme arasındaki ilişkide etki büyüklüğünün hesaplanması için Pearson korelasyon katsayısı kullanılmıştır. Standart hata, varyans ve Fisher Z değerleri Tablo 2'de gösterilmiştir.

Tablo 2

Dönüşümcü Liderlik İle Örgütsel Özdeşleşme Arasındaki Illişki Düzeyini Gösteren Bireysel Çalışmalara Ait Bulgular ve Etki Büyüklükleri

\begin{tabular}{|c|c|c|c|c|c|}
\hline Çalışma Adı & $\mathrm{r}$ & $\mathrm{N}$ & $\begin{array}{c}\text { Standart } \\
\text { Hata }\end{array}$ & Varyans & $\begin{array}{c}\text { Fisher's Z } \\
\text { Değeri }\end{array}$ \\
\hline İşcan (2006) & 0.310 & 213 & 0.069 & 0.005 & 0.321 \\
\hline Özsöylemez (2009) & 0.589 & 148 & 0.083 & 0.007 & 0.676 \\
\hline Çeri-Booms (2009) & 0.292 & 232 & 0.066 & 0.004 & 0.301 \\
\hline Güngör (2010) & 0.250 & 317 & 0.056 & 0.003 & 0.255 \\
\hline Eren ve Çakır-Titizoğlu (2014) & 0.398 & 352 & 0.054 & 0.003 & 0.421 \\
\hline Çulhaoğlu-Uludağ (2015) & 0.286 & 250 & 0.064 & 0.004 & 0.294 \\
\hline Erdoğan-Morçin ve Çarıkçı (2016) & 0.460 & 644 & 0.039 & 0.002 & 0.497 \\
\hline Temel (2016) & 0.453 & 147 & 0.083 & 0.007 & 0.488 \\
\hline Karsli (2019) & 0.425 & 231 & 0.066 & 0.004 & 0.454 \\
\hline Alagöz (2019) & 0.250 & 193 & 0.073 & 0.005 & 0.255 \\
\hline Doğanlı (2019) & 0.300 & 227 & 0.067 & 0.004 & 0.310 \\
\hline
\end{tabular}

Tablo 2'ye göre, dönüşümcü liderlik ile örgütsel özdeşleşme arasındaki ilişkiyi Türkiye örneklemini kullanarak ele almış olan 11 bireysel çalışmanın meta-analize dahil edildiği anlaşılmaktadır. Bireysel çalışmaların Fisher's Z değerine göre etki büyüklükleri (0.255) ile (0.676) arasındadır. Özsöylemez'in (2009) yüksek lisans tezi ile Alagöz'ün (2019) yüksek lisans tezinin etki büyüklüklerinin uç noktaları temsil ettiği anlaşılmaktadır. Analize dahil edilmiş olan bireysel çalışmalara yönelik etki büyüklüklerinin hesaplanmasıyla birlikte genel etki büyüklügünün hesaplanması için homojenlik-heterojenlik testleri yapılarak analiz modeli belirlenmektedir. Yapılan testlerin sonucuna göre kritik değeri aşıp aşmamasına ve anlamlılık değerinin 0.05 'ten küçük olup olmamasına bağlı kalarak uygun analiz modeli (sabit veya rastgele etki modeli) seçilmektedir. Ellis'in (2010) belirttiğine göre, elde edilen etki büyüklükleri ortak bir etki büyüklüğünü paylaşması ve homojen dağılması halinde sabit etki modeli tercih edilirken; gerçek etki büyüklügünün tüm çalışmalarda aynı olmayacağından dolayı ortaya çıkan farklı etki büyüklüklerinde rastgele etki büyüklüğü tercih edilmektedir (Hedges ve Vevea, 1998). Dönüşümcü liderlik ve örgütsel özdeşleşme arasındaki ilişkinin genel etki büyüklügünün hesaplanması için kullanılacak modelin seçimi için heterojenlik testi sonuçlarına Tablo 3 ’te yer verilmiştir.

Tablo 3

Dönüşümcü Liderlik Ille Örgütsel Özdeşleşme Arasındaki Korelasyona Ait Heterojenlik Testi Sonuçları

\begin{tabular}{lcccccccc}
\hline Model & \multicolumn{3}{c}{ Etki Büyüklüğünün \%95 Güven Aralığı } & \multicolumn{5}{c}{ Heterojenlik Testi } \\
\hline Model & Çalışma sayısı & $\begin{array}{c}\text { Nokta } \\
\text { tahmini } \\
(\mathrm{r})\end{array}$ & Alt sınır & Üst sınır & $\begin{array}{c}\text { Q değeri } \\
\mathrm{x}^{2}\end{array}$ & $\begin{array}{c}\text { Serbestlik } \\
\text { Derecesi }\end{array}$ & $\mathrm{P}$ & $\mathrm{I}^{2}$ \\
\hline Sabit & 11 & 0.393 & 0.356 & 0.429 & 37.813 & 10 & 0.000 & 73.544 \\
Rastgele & 11 & 0.386 & 0.313 & 0.458 & & & & \\
\hline
\end{tabular}

Tablo 3'e bakıldığında hesaplanan ki-kare $\left(\mathrm{x}^{2}\right)$ değerinin 37.813 olduğu görülmektedir. Elde edilen bu değer, ki-kare 0.05 anlamlılık düzeyi ve 10 serbestlik derecesine karş1lı gelen değerin (18.307) üzerindedir. Kritik değeri aştı̆ğ görülen tablo değerine ve anlamlılık değerinin $p<0.05(p=0.00)$ olmasına bağlı olarak dönüşümcü liderlik ile örgütsel özdeşleşme ilişkisi için meta-analize dahil edilen 11 çalışmanın etki büyüklüklerinin homojen dağılmadıkları anlaşılmaktadır. Bu durumda homojenlik 
reddedilerek heterojenlik düzeyini tespit etmek üzere Higgins değerine $\left(\mathrm{I}^{2}\right)$ bakılmıştır. Tablo 3'e göre ilgili değerin 73.544 olduğu görülmektedir. Higgins ve Tompson'ın (2002) çalışmasında da belirttiği üzere, bu değerin $\% 30$ düzeyinde olması düşük heterojenlik, $\% 50$ düzeyinde olması yüksek heterojenlik ve \%70 düzeyinin üzerinde olması halinde oldukça yüksek bir heterojenlik vardır (Petticrew ve Roberts, 2006). Dönüşümcü liderlik ile örgütsel özdeşleşme arasındaki ilişki için hesaplanmış olan değerin yüksek heterojenliği temsil ettiği anlaşılmaktadır.

Tablo 4

Rastgele etki modeliyle etki büyüklüğü değeri (Dönüşümcü liderlik)

\begin{tabular}{lcccc}
\hline Çalışma Adı & \multirow{2}{*}{ Fisher's Z Değeri } & $\begin{array}{c}\text { Alt } \\
\text { Limit }\end{array}$ & $\begin{array}{c}\text { Üst } \\
\text { Limit }\end{array}$ & Z Değeri \\
\hline İşcan (2006) & 0.321 & 0.185 & 0.456 & 4.645 \\
Özsöylemez (2009) & 0.676 & 0.513 & 0.839 & 8.142 \\
Çeri-Booms (2009) & 0.301 & 0.171 & 0.430 & 4.551 \\
Güngör (2010) & 0.255 & 0.145 & 0.366 & 4.526 \\
Eren ve Çakır-Titizoğlu (2014) & 0.421 & 0.316 & 0.526 & 7.870 \\
Çulhaoğlu-Uludağ (2015) & 0.294 & 0.169 & 0.419 & 4.624 \\
Erdoğan-Morçin ve Çarıkçı (2016) & 0.497 & 0.421 & 0.574 & 12.786 \\
Temel (2016) & 0.488 & 0.325 & 0.652 & 5.862 \\
Karslı (2019) & 0.454 & 0.324 & 0.584 & 6.852 \\
Alagöz (2019) & 0.255 & 0.113 & 0.398 & 3.521 \\
Doğanlı (2019) & 0.310 & 0.179 & 0.440 & 4.632 \\
\hline Rastgele etki modeli & $\mathbf{0 . 3 8 6}$ & $\mathbf{0 . 3 1 3}$ & $\mathbf{0 . 4 5 8}$ & $\mathbf{1 0 . 4 6 0}$ \\
\hline
\end{tabular}

Tablo 4'te gösterilmiş olan bulgulara bağlı kalınarak, dönüşümcü liderlik ile örgütsel özdeşleşme arasında pozitif yönlü bir ilişkiyi sorgulayan birinci alt problem, ilişkinin varlığı tespit edilerek cevaplanmıştır. Elde edilen etki büyüklüğü değeri $\mathrm{r}=0.386$ Cohen, Manion ve Morrison'a (2007) göre orta düzeyde bir etkiye sahiptir. Analize dahil edilen 11 bireysel çalışmanın sonuçlarından rastgele etki modeliyle elde edilen değeri içeren Tablo 4'deki dağılımlar da Fisher's z değerine göre belirtmektedir. Tablo 4'e göre rastgele etki modeli etki büyüklüğü değeri 0.037 hata ile 0.386 olarak bulgulanmıştır. Etki büyüklügünün alt limiti 0.313 ve üst limiti 0.458 'dir.

\section{Etkileşimci Liderlik İle Örgütsel Özdeşleşme Arasındaki İlişkide Etki Büyüklüğü Bulguları}

Etkileşimci liderlik ile örgütsel özdeşleşme arasındaki ilişkide etki büyüklügünün hesaplanması için de Pearson korelasyon katsayısı kullanılmıştır. Standart hata, varyans ve Fisher Z değerleri Tablo 5 'te gösterilmiştir.

Tablo 5

Etkileşimci Liderlik İle Örgütsel Özdeşleşme Arasındaki İlişki Düzeyini Gösteren Bireysel Çalışmalara Ait Bulgular ve Etki Büyüklükleri

\begin{tabular}{lccccc}
\hline Çalışma Adı & $\mathrm{r}$ & $\mathrm{N}$ & $\begin{array}{c}\text { Standart } \\
\text { Hata }\end{array}$ & Varyans & $\begin{array}{c}\text { Fisher's Z } \\
\text { Değeri }\end{array}$ \\
\hline İşcan (2006) & 0.310 & 213 & 0.069 & 0.005 & 0.321 \\
Çeri-Booms (2009) & 0.250 & 232 & 0.066 & 0.004 & 0.255 \\
Erdoğan-Morçin ve Morçin (2013) & 0.365 & 153 & 0.082 & 0.007 & 0.383 \\
Eren ve Çakır-Titizoğlu (2014) & 0.257 & 352 & 0.054 & 0.003 & 0.263 \\
Çulhaoğlu-Uludağ (2015) & 0.284 & 250 & 0.064 & 0.004 & 0.292 \\
Erdoğan-Morçin ve Çarıkçı (2016) & 0.498 & 644 & 0.039 & 0.002 & 0.547 \\
\hline
\end{tabular}

Tablo 5'e göre, etkileşimci liderlik ile örgütsel özdeşleşme arasındaki ilişkiyi Türkiye örneklemini kullanarak ele almış olan altı bireysel çalışmanın meta-analize dahil edildiği anlaşılmaktadır. Bireysel çalışmaların Fisher's Z değerine göre etki büyüklükleri (0.255) ile (0.547) arasındadır. Çeri-Booms'un (2009) doktora tezi ile Eroğan-Morçin ve Morçin'in (2013) makalesinin etki büyüklüklerinin uç noktaları temsil ettiği anlaşılmaktadır. Etkileşimci liderlik ve örgütsel 
özdeşleşme arasındaki ilişkinin genel etki büyüklüğünün hesaplanması için kullanılacak modelin seçimi için heterojenlik testi sonuçlarına Tablo 4'te yer verilmiştir.

Tablo 6

Etkileşimci Liderlik Ile Örgütsel Özdeşleşme Arasındaki Korelasyona Ait Heterojenlik Testi Sonuçları

\begin{tabular}{lcccccccc}
\hline Model & \multicolumn{3}{c}{ Etki Büyükklüğünün \%95 Güven Aralığı } & \multicolumn{5}{c}{ Heterojenlik Testi } \\
\hline Model & Çalışma sayısı & $\begin{array}{c}\text { Nokta } \\
\text { tahmini } \\
(\mathrm{r})\end{array}$ & Alt sınır & Üst sınır & $\begin{array}{c}\text { Q değeri } \\
\mathrm{x}^{2}\end{array}$ & $\begin{array}{c}\text { Serbestlik } \\
\text { Derecesi }\end{array}$ & $\mathrm{P}$ & $\mathrm{I}^{2}$ \\
\hline Sabit & 6 & 0.382 & 0.336 & 0.428 & 28.789 & 5 & 0.000 & 82.632 \\
Rastgele & 6 & 0.347 & 0.232 & 0.461 & & & & \\
\hline
\end{tabular}

Tablo 6'ya bakıldığında hesaplanan ki-kare $\left(\mathrm{x}^{2}\right)$ değerinin 28.789 olduğu görülmektedir. Elde edilen bu değer, ki-kare 0.05 anlamlılık düzeyi ve 5 serbestlik derecesine karşılık gelen değerin (11.070) üzerindedir. Kritik değeri aştığı görülen tablo değerine ve anlamlılık değerinin $p<0.05(p=0.00)$ olmasına bağlı olarak etkileşimci liderlik ile örgütsel özdeşleşme ilişkisi için meta-analizine dahil edilen 6 çalışmanın etki büyüklüklerinin homojen dağılmadıkları anlaşılmaktadır. Bu durumda homojenlik reddedilerek heterojenlik düzeyini tespit etmek üzere Higgins değerine $\left(\mathrm{I}^{2}\right)$ bakılmıştır. Tablo 6 'ya göre ilgili değerin 82.632 olduğu görülmektedir. Etkileşimci liderlik ile örgütsel özdeşleşme arasındaki ilişki için hesaplanmış olan değerin yüksek heterojenliği temsil ettiği anlaşılmaktadır.

Tablo 7

Rastgele etki modeliyle etki büyüklügü değeri (Etkileşimci liderlik)

\begin{tabular}{lcccc}
\hline Çalışma Adı & \multirow{2}{*}{ Fisher's Z Değeri } & $\begin{array}{c}\text { Alt } \\
\text { Limit }\end{array}$ & $\begin{array}{c}\text { Üst } \\
\text { Limit }\end{array}$ & Z Değeri \\
\hline İşcan (2006) & 0.321 & 0.185 & 0.456 & 4.645 \\
Çeri-Booms (2009) & 0.255 & 0.126 & 0.385 & 3.865 \\
Erdoğan-Morçin ve Morçin (2013) & 0.383 & 0.223 & 0.543 & 4.686 \\
Eren ve Çakır-Titizoğlu (2014) & 0.263 & 0.158 & 0.368 & 4.911 \\
Çulhaoğlu-Uludağ (2015) & 0.292 & 0.167 & 0.417 & 4.590 \\
Erdoğan-Morçin ve Çarıkçı (2016) & 0.547 & 0.469 & 0.624 & 13.840 \\
\hline Rastgele etki modeli & $\mathbf{0 . 3 4 7}$ & $\mathbf{0 . 2 3 2}$ & $\mathbf{0 . 4 6 1}$ & $\mathbf{5 . 9 3 4}$ \\
\hline
\end{tabular}

Tablo 7'de gösterilmiş olan bulgulara bağlı kalınarak, etkileşimci liderlik ile örgütsel özdeşleşme arasında pozitif yönlü bir ilişkiyi sorgulayan üçüncü alt problem, ilişkinin varlığ 1 tespit edilerek cevaplanmıştır. Elde edilen etki büyüklüğü değeri r=0.347 Cohen, Manion ve Morrison'a (2007) göre orta düzeyde bir etkiye sahiptir. Analize dahil edilen altı bireysel çalışmanın sonuçlarından rastgele etki modeliyle elde edilen değeri içeren Tablo 7'deki dağılımlar da Fisher's z değerine göre belirtmektedir. Tablo 7'ye göre rastgele etki modeli etki büyüklüğü değeri 0.058 hata ile 0.347 olarak bulgulanmıştır. Etki büyüklüğünün alt limiti 0.212 ve üst limiti 0.461 'dir.

\section{Dönüşümcü Liderlik ve Etkileşimci Liderlik İle Örgütsel Özdeşleşme Arasındaki İlişkide Yayın Yanlılı̆̆ı}

Hesaplanan genel etki büyüklügünün ardından meta-analiz çalışmalarında önemli bir kısıt olarak kabule edilen ve değişkenler arasındaki ilişkiyle alakalı tüm bireysel çalışmaların yanlı bir örneklemi temsil ediyor olması yanılgısını (Hunter ve Schmidt, 2004) açılayan yayın yanlılı̆̆ için de analizler yapılmıştır. Dickersin, Min ve Meinert'in (1992) belirttiği üzere, yayınlanan bireysel çalışmaların sonuçlarında baskın olarak istatistiki anlamlı sonuçlara sahip olanlara yer verildiği iddia edilmektedir. Böyle bir durumda da yayın yanlılığı ortaya çıkmaktadır (Rosenthal, 1979). Yayın yanlılı̆̆ının gerçekleşmesi halinde, meta-analize dahil edilen bireysel çalışmaların etki büyüklükleri de kaçınılmaz olarak bu durumdan etkilenip sapma gösterebilecektir. Buna bağlı olarak da ulaşılması beklenen sonuçlarda da istatistiksel olarak anlamlı olan sonuçlar kendini göstermeketdir (Field ve Gillett, 2010). Analize dahil edilen bireysel çalışmaların etki büyüklüklerinin dağılımını ve buna bağlı oluşabilecek yayın yanlılığının olasılığını gösteren huni saçılım grafiği kullanılan yaygın bir yöntemdir. Bu yöntemle elde edilen dağılıma göre bireysel çalışmaların değerlerinin huni çevresinde simetrik olarak dağılmaları 
beklenir. Huni saçılım grafiklerinin çizilmesiyle birlikte, dönüşümcü liderlik ile örgütsel özdeşleşme arasındaki ilişkisiyi ele almış olan bireysel çalışmalardaki gözlenen değerlerle yayın yanlılığından doğabilecek etkiyi düzeltmek amacıyla belirtilen ve düzeltilmiş değerler arasında bir farklılık olmadığı söylenebilir. Bu durumda da merkez çizgisi etrafında kayıp bir veriye rastlanılmadığı ve meta-analize dahil edilen 11 bireysel çalışmanın bu çizginin iki tarafında yoğunlaşarak simetrik bir dağılım gösterdiği ifade edilebilmektedir. Etkileşimci liderlik ile örgütsel özdeşleşme arasındaki ilişkiyi ele almış olan bireysel çalışmaların değerleriyle çizilmiş olan grafiğe bakldığında ise etkileşimci liderlik ile örgütsel özdeşleşme ilişkisini ele almış olan bireysel çalışmalardaki gözlenen değerlerle yayın yanlılığından doğabilecek etkiyi düzeltmek amacıyla belirtilen ve düzeltilmiş değerler arasında bir farklılık olmadığı yine söylenebilir, ancak sola doğru bir yığılma olduğu da açıcça anlaşılmaktadır. Fakat, yayın yanlılığını açıklamada yalnızca huni grafiğinin yeterli olmadığı bilinmektedir (Petticrew ve Roberts, 2006). Bu nedenle yayın yanlılığının test edilmesinde en güvenilir istatistiklerden olan Begg ve Mazumdar'ın (1994) sıra korelasyon testi uygulanarak, örgütsel özdeşleşmenin her iki liderlik türü ile olan ilişkisi için Kendall Tau katsayısına da bakılmıştır. Yayın yanlılığının olmadığı ortaya konulurken gerçek etki büyüklüğünün varyansı olarak ifade edilen Tau katsayısı 1'e yakın bir değere sahip olup iki kuyruklu p değerinin de anlamlılık göstermemesi ( $\mathrm{p}>0.05$ ) beklenmektedir (Dinçer, 2014). Dönüşümcü liderlik için elde edilen test sonucuna göre Tau katsayısının 0.146; $p$ değerinin ise 0.267 olduğu, etkileşimci liderlik için ise Tau katsayısının 0.133; p değerinin ise 0.354 olduğu sonucuna ulaşılmıştır. Bu sonuçlara göre, her iki liderlik türünün örgütsel özdeşleşmeyle olan ilişkisini ele almış olan bireysel çalışmaların sonuçlarına göre yayın yanlılığının olmadığını ifade edilmektedir. Bir başka istatistik olan Rosenthal'in değerine göre ise, yayın yanlılığından söz edebilmek için elde edilen değerin dönüşümcü liderlik için en az $5 \times 11+10=65$ değerinden küçük olması beklenir. Yapılan test sonucunda elde edilen 1194 değerinin ise 65 'ten oldukça büyük olduğu görülmektedir. Benzer şekilde etkileşimci liderlik için de en az $5 \times 6+10=40$ değerinden küçük olması beklenir. Yapılan test sonucunda elde edilen 342 değerinin ise 40'tan oldukça büyük olduğu görülmektedir. Bu sayede de yayın yanlılığının olmadığ 1 ifade edilebilir. Egger, Davey-Smith, Schneider ve Minder'in (1977) öne sürdüğü bir diğer istatistikte doğrusal regresyon yaklaşımı da ele alınmaktadır. Test değerinin, simetrik bir huni için regresyon çizgisinin orijinden geçmesi ve elde edilen beta değerinin de sıfır olması beklenmektedir. Dönüşümcü liderlik ve etkileşimci liderlik ile örgütsel özdeşleşme arasındaki ilişkinin yayın yanlılığının tespiti için yapılan Egger regresyon analizi sonucuna göre $\mathrm{t}$ test sonucunun tek yönlü testinin dünüştürücü liderlik $(\mathrm{t}=0.5517 ; \mathrm{p}=0.297)$ ve etkileşimci liderlik $(\mathrm{t}=2.049 ; \mathrm{p}=0.060)$ anlamsız olduğu görülmektedir. $\mathrm{Bu}$ da yayın yanlılığının olmadığının bir başka göstergesi olarak kabul edilebilir.

\section{Dönüşümcü Liderlik İle Örgütsel Özdeşleşme Arasındaki İlişkide Alt Grup veya Moderatör Etki Bulguları}

Meta-analizde, alt gruplar arasında bir farklılık olup olmadığını, farklılık olması durumunda bu farklılığın yönü ve değişkenlerin ortalama etki büyüklükleri arasındaki farklılığı tespit eden moderatör etki analizi (Littel, Corcoran ve Pillai, 2008; Akt. Ulubey ve Toraman, 2015) bulgularıyla, değişkenler arasındaki farklılı̆̆ın istatistiki anlamlılığı $\mathrm{Q}_{b}$ değeriyle yorumlanır. Dönüşümcü liderlik ile örgütsel özdeşleşme arasındaki ilişkiyi ele alan ve meta-analize dahil edilmiş olan 11 bireysel çalışmanın etki büyüklükleri, çalışmanın yayın türü (doktora tezi (Tez (D), yüksek lisans tezi (Tez (YL)) ve makale), yayın yılı, dönüşümcü liderlik ölçekleri, örgütsel özdeşleşme ölçekleri ve çalışmanın yapıldığı sektör bakımından farklılık gösterip göstermediğine bakmakılmak üzere moderatör etki analiziyle test edilmiştir. Yapılan moderatör etki analizleri sonucuna göre; dönüşümcü liderlik ile örgütsel özdeşleşme arasındaki ilişkiyi konu alan 11 bireysel çalışmanın üç farklı yayın türü (doktora tezi (Tez (D)), yüksek lisans tezi (tez (YL)) ve makale) olduğu görülmektedir. Yayın türlerinin etki büyüklüklerinin Tez $(D)=0.297$; Makale=0.426 değerlerine sahip olmak üzere geniş bir aralıkta yer aldığ olduğu görülmektedir. Elde edilen $\mathrm{Q}_{b}$ değerinin (3.991) kritik değerin (5.991) altında olduğundan dolayı yayın türünün, dönüşümcü liderlik ile örgütsel özdeşleşme arasındaki pozitif ilişkide moderatör olmadığ1 sonucuna ulaşılmıştır. Yayın yılına bakıldığında, meta-analize dahil edilen 11 bireysel çalışmanın 20062019 yılları arasında yürütüldüğü anlaşılmaktadır. Dönüşümcü liderlik ile örgütsel özdeşleşme ilişkisini konu alan çalışmaların yıllara göre etki büyüklüklerinin 2006-2009 yılları arasında 0.428; 2010-2014 yılları arasında 0.083 ve 2015-2019 yılları arasında 0.047 olmak üzere oldukça büyük farklılık vardır. Elde edilen $\mathrm{Q}_{b}$ değerinin (0.437) ise kritik değerin (5.991) altında olduğu tespit edilmiştir. Bu durumda, 
yayın yılının dönüşümcü liderlik ile örgütsel özdeşleşme arasındaki pozitif ilişkide moderatör olmadığ1 sonucuna ulaşılmıştır. Dönüşümcü liderlik ve örgütsel özdeşleşme arasındaki ilişkiyi konu almış olan 11 bireysel çalışmada araştırmacıların tercih ettiği dönüşümcü liderlik ölçeklerinin iki farklı türde olduğu ve en çok tercih edilenin ( $\mathrm{k}=8)$ ise Bass ve Avolio'nun (1990) geliştirdiği ölçek olduğu bilinmektedir. Kullanılan ölçeklerin etki büyüklükleri Podsakoff vd. $(1990)=0.346$; Avolio, Bass ve Jung $(1999)=0.401$ olmak üzere yakın bir aralıkta yer aldığı açıktır. Hesaplanan $\mathrm{Q}_{b}$ değerinin $(0.535)$ kritik değerin $(3,841)$ altında seyretti için araştırmacılarca tercih edilen dönüşümcü liderlik ölçeklerinin dönüşümcü liderlik ile örgütsel özdeşleşme arasındaki pozitif ilişkide moderatör olmadığ1 anlaşılmaktadır. Bireysel araştırmalarda tercih edilen örgütsel özdeşleşme ölçeklerinde üç farklı tür olduğu görülmektedir. En çok tercih edilen $(k=9)$ örgütsel özdeşleşme ölçeğinin Mael ve Ashforth'un (1992) ölçeği olduğu anlaşılmaktadır. Kullanılan bu ölçeklerin etki büyüklüklülerinin ise VanDick Wagner, Stellmacher ve Chris (2004) ile Cheney (1983) $=0.589$ arasında seyrettiği; elde edilen $\mathrm{Q}_{b}$ değerinin (0.506) kritik değerin (3.841) oldukça altında olduğu için kullanılan ölçeğin farklılık oluşturmadığı söylenebilir. Bu durumda da araştırmacılar tarafindan tercih edilen örgütsel özdeşleşme ölçekleri, dönüşümcü liderlik ile örgütsel özdeşleşme arasındaki pozitif ilişkide moderatördür olmadığı sonucuna ulaşılmıştır. Analize dahil edilen 11 bireysel çalışmanın sekiz tanesinin özel sektörde ve üç tanesinin de kamu sektöründe uygulandığı anlaşılmaktadır. Bireysel çalışmaların yapıldığ1 sektör için hesaplanan etki büyüklüklerinin birbirine oldukça yakın (Özel=0.366; Kamu=0.373) olduğu görülmektedir. Hesaplanan bu etki büyüklüklerine göre hesaplanan $\mathrm{Q}_{b}$ istatistik değeri 0.008 'dir. Elde edilen $\mathrm{Q}_{b}$ değeri, kritik değerin (3.841) altındadır; bu durumda sektörler arasında bir farklılık olmadığ ifade edilebilir. Bu durumda araştırmanın yapıldığı sektör, dönüşümcü liderlik ile örgütsel özdeşleşme arasındaki pozitif ilişkide moderatör değildir sonucuna ulaşılarak belirlenen ikinci alt problem, yayın y1lı, yayın türü, dönüşümcü liderlik ölçekleri, örgütsel özdeşleşme ölçekleri ve sektörün dönüşümcü liderlik ile örgütsel özdeşleşme arasındaki pozitif ilişkide moderatör olmadığ 1 anlaşılmaktadır.

\section{Etkileşimci Liderlik İle Örgütsel Özdeşleşme Arasındaki İlişkide Alt Grup veya Moderatör Etki Bulguları}

Etkileşimci liderlik ile örgütsel özdeşleşme arasındaki ilişkiyi ele alan ve meta-analize dahil edilmi olan altı çalışmanın etki büyüklükleri, çalışmanın yayın türü (doktora tezi (Tez (D)) ve makale), yayın yılı, etkileşimci liderlik ölçekleri, örgütsel özdeşleşme ölçekleri ve çalışmanın yapıldığı sektör bakımından farklılık gösterip göstermediğine bakılmak üzere moderatör analiziyle test edilmiştir. Yapılan moderatör etki analizleri sonucuna göre; etkileşimci liderlik ile örgütsel özdeşleşme arasındaki ilişkiyi konu alan altı bireysel çalışmanın doktora tezi (Tez (D)) ve makale olmak üzere iki farklı yayın türünde yapılmış olduğu görülmektedir. Yayın türlerinin etki büyüklüklerinin Tez (D) $=0.274$; Makale $=0.382$ olmak üzere geniş bir aralıkta yer almaktadır. Elde edilen $\mathrm{Q}_{b}$ değerinin (1.429) kritik değerin (3.841) altında seyretmesinden dolayı yayın türünün, etkileşimci liderlik ile örgütsel özdeşleşme arasındaki pozitif ilişkide moderatör olmadığı sonucuna ulaşılmıştır. Yayın yılına bakıldığında, metaanalize dahil edilen altı bireysel çalışmanın 2006-2016 yılları arasında yürütüldüğü anlaşılmaktadır. Etkileşimci liderlik ile örgütsel özdeşleşme ilişkisini konu alan çalışmaların yıllara göre etki büyüklüklerinin $(2009=0.250 ; 2016=0.498)$ arasında oldukça düşük düzeyde bir farklılık vardır. Elde edilen $\mathrm{Q}_{b}$ değerinin (0.598) ise kritik değerin (3.841) çok altında olduğu tespit edilmiştir. Bu durumda yayın yılı, etkileşimci liderlik ile örgütsel özdeşleşme arasındaki pozitif ilişkide moderatör olmadığı sonucuna ulaşılmıştır. Etkileşimci liderlik ve örgütsel özdeşleşme arasındaki ilişkiyi konu almış olan altı bireysel çalışmada araştırmacıların tercih etmiş olduğu etkileşimci liderlik ölçeklerinin üç farklı türde olduğu ve en çok tercih edilenin (k=4) Bass ve Avolio'nun (1990) geliştirdiği ölçek olduğu bilinmektedir. Kullanılan ölçeklerin etki büyüklükleri Bass ve Avolio (1990) ve Avolio, Bass ve Jung $(1999)=0.287$ ve diğer olarakkategarize edilen ölçeklerin etki büyüklüğü 0.441 olmak üzere geniş bir aralıkta yer aldığı açıktır. Hesaplanan $\mathrm{Q}_{b}$ değerinin (1.718) kritik değerin (3.841) çok altında seyretti için araştırmacılarca tercih edilen etkileşimci liderlik ölçeklerinin etkileşimci liderlik ile örgütsel özdeşleşme arasındaki pozitif ilişkide moderatör olmadığı anlaşılmaktadır. Analize dahil edilmiş oan altı bireysel çalışmada tercih edilmiş olan örgütsel özdeşleşme ölçeklerinin iki farklı ölçek türünde olduğu görülmektedir. En çok tercih edilen $(k=5)$ örgütsel özdeşleşme ölçeğinin Mael ve Ashforth'un (1992) ölçeği olduğu görülmektedir. Kullanılan bu ölçeklerin etki büyüklüklülerinin ise VanDick vd. $(2004)=0.310$; Mael ve Ashforth'un $(1992)=0.337$ arasında seyrettiği; ancak elde edilen $\mathrm{Q}_{b}$ değerinin 
(0.099) kritik değerin (3.841) altında kaldığı için kullanılan ölçeğin farklılık oluşturmadığı söylenebilir. Bu durumda da araştırmacılar tarafından tercih edilen örgütsel özdeşleşme ölçekleri, etkileşimci liderlik ile örgütsel özdeşleşme arasındaki pozitif ilişkide moderatör değildir sonucuna ulaşılmıştır. Analize dahil edilen altı bireysel çalışmanın tamamının özel sektörde uygulandığı bilinmektedir. Elde edilen etki büyüklügü Özel=0.364 ve hesaplanan bu etki büyüklüklerine göre $\mathrm{Q}_{b}$ istatistik değeri 0.000 'dır. Elde edilen $\mathrm{Q}_{b}$ değeri farklılık olmadığ etkileşimci liderlik ile örgütsel özdeşleşme arasındaki pozitif ilişkide moderatör değildir sonucuna ulaşılarak dördüncü alt problemde yayın yılı, yayın türü, dönüşümcü liderlik ölçekleri, örgütsel özdeşleşme ölçekleri ve sektörün dönüşümcü liderlik ile örgütsel özdeşleşme arasındaki pozitif ilişkide moderatör olmadığı anlaşılmaktadır.

\section{Sonuç, Tartıșma ve Öneriler}

Yapılan bu meta-analiz çalışması sayesinde hem ülkemizde hem de uluslararası yazında büyük ilgiyle üstünde durulan ve çalışmalar yapılan iki liderlik türü olarak dönüşümcü lidelik ve etkileşimci liderliğin örgütler için anlamı ve önemi çok fazla olan örgütsel özdeşleşme kavramıyla olan ilişkisini ele alan bireysel çalışmalar ( $\mathrm{k}=17, \mathrm{n}=4798)$ incelenmiştir. Homojenlik-heterojenlik durum tespiti yapılarak sabit-rastgele etki büyüklüğününden hangisinin uygulanacğına karar verilmiştir. Her iki liderlik türü için yapılan testler sonucunda rastgele etki büyüklüğünün seçilmesine karar verilerek iki liderlik türünün örgütsel özdeşleşmeyle olan ilişkisi üzerinden ayrı ayrı meta-analiz yapılarak etki büyüklükleri saptamıştır. Bunların yanı sıra dönüşümcü lidelik ve etkileşimci liderlik ile örgütsel özdeşleşme arasındaki ilişkiler üzerinde çalışmanın yapıldığ 1 tür, çalışmanın yapıldığ yıl, kullanılan ölçek türleri, çalışmanın yürütüldüğü sektör değişkenlerinin moderatör etkisinin olup olmadığına bakılmak amacıyla beşer farklı moderatör etki analizi yapılmıştır. Yapılan bu analizlerin sonucunda ilişkilerin yönü ve gücü ortaya konularak moderatör değişkenlerin etkisinin de anlamlı olup olmadığ 1 ayrıca tespit edilmiştir.

Öncelikle dönüşümcü liderlik ile örgütsel özdeşleşme arasındaki ilişkiyi ele alan 11 bireysel çalışmanın sonuçları analize alınarak genel etki büyüklüğü $r=0.386, p<0.05$ olarak hesaplanmıştır. Dönüşümcü liderlik, çalışanların örgütün değerlerini benimseyip örgütle birlik ve bütünlük içerisinde olarak katılım göstermesini, örgütleriyle özdeşim kurmalarını böylelikle de potansiyellerini performansa dönüştürmesini sağlamaktadırlar (Bryman, 1992). Örgüt amaçlarıyla özdeşleşen çalışanların, liderlerinin önemli davranış kalıplarını da benimsedikleri açıktır. Bu sayede de liderin davranışları bir rol model oluşturarak örgütsel özdeşleşme için pozitif bir etki oluşturmaktadır (Podsakoff vd., 1990). Liderlerine benzeme arzusu içindeki çalışanların örgüt için de istekli bir şekilde çaba göstermek isteyecekleri için liderlerini yüksek düzeyde benimsemeleri sayesinde örgütsel özdeşleşmeleri daha da kolaylaşmaktadır (Demir ve Okan, 2008). Benzer şekilde Avolio ve Gibbons (1998) da diğer araştırmacılar gibi, dönüşümcü liderliğin örgütsel özdeşleşmeye olumlu etkiler oluşturduğu sonucuna ulaşmıştır (Epitropaki ve Martin, 2005). Sonuç olarak, çalışanlarının (takipçilerinin) fikirlerini önemseyen ve onların gelişim ve değişimleri için çaba gösteren liderlik türü olan dönüşümcü liderlik, örgütsel özdeşleşmeyle pozitif manada yakından ilişkilidir (Greenberg ve Baron, 2000). Böylece birinci alt problem yazınla paralellik göstererek cevaplanmıştır. Ayrıca, 11 çalışmanın etki büyüklük değerlerinin alt ve üst sınırları da sırasıyla 0.313-0.458 olarak bulgulanmıştır. Aynı işlemin etkileşimci liderlik ile örgütsel özdeşleşme arasındaki ilişkiyi ele alan altı bireysel çalışma için de yapılmasıyla etki büyüklük değeri $\mathrm{r}=0.347, \mathrm{p}<0.05$ olarak hesaplanmıştır. Alt ve üst sınırların ise sırasıyla 0.232-0.461 olduğu görülmüştür. Sıklıklı dönüşümcü liderlik ile beraber incelenen etkileşimci liderliğin örgütsel özdeşleşmeyle ilişki içinde olduğunu bulgulayan çalışmalarda, liderin çalışanlardan beklentilerinin yerine getirilmesinde ve lidere sadakatla bağlanılarak itaat edilmesi halinde çalışanlarının kazanımlarını açık bir şekilde ortaya koyduğu (Pillai, Schriesheim ve Williams, 1999), böylece yaşanan bu etkin iletişim ve etkileşimle çalışanların kendilerini örgütlerinin birer parçası gibi hissetmeleri sağlanmaktadır. Daha çok küçük ölçekli ve ağırlıklı olarak rutinleşen süreçte değilişiklikler gerektiren işlerde kendini gösteren etkileşimci liderler (Black ve Porter, 2000), çalışanlarının onu izlerken onun belirlediği kurallardan şaşmadan hareket etmelerini bekler. Sınırları net belirlenmiş olan bu liderlik, adeta bir ailedeki yerleşmiş olan kurallar gibidir. Böylece, çalışanlar da kendilerini küçük bir topluluğun içinde belirsizlikten uzak ve güven içinde hissederek çalışmaktadır (Geijesel, Sleegers ve VanDen Berg, 
1999). Deyim yerindeyse, liderle çalışanlar arasında bir çeşit takası anlatan etkileşimci liderlik, karşılıklı ihtiyaçların gözetilerek karşılanmasıyla çıkar çatışması olmaksızın fayda sağlamaya odaklanmaktadır (Shriberg Shriberg ve Lloyd, 2002). Yazınla paralellik gösteren bulgular sayesinde üçüncü alt problem cevaplanmıştır. $\mathrm{Bu}$ iki liderlik türünün örgütsel özdeşleşmeyle olan ilişkisinde etki büyüklük değerlerinin birbirine yakın seyrettiği anlaşılmaktadır. Tıpk1 Epitropaki ve Martin'in (2005) bireysel çalışmasında olduğu gibi yapılan bu meta-analiz çalışması sonucuna göre dönüşümcü liderliğin etkileşimci liderliğe nazaran örgütsel özdeşleşme üzerinde daha fazla etki oluşturduğu bulgulanmıştır.

Örgütsel özdeşleşme ile dönüşümcü liderlik ve etkileşimci liderlik arasındaki ilişkilerde çalışmaların yapıldığı yayın türleri, yayın yılı ve uygulandıkları sektörün moderatör etkisini ulaşılmamıştır. Benzer bir şekilde moderatör etki, kullanılan ölçek türlerinde de görülmemektedir. Araştırmacılar tarafından bireysel çalışmalardaki tercih edilmiş olan ölçeklere verilen cevap, katılımcılar tarafından ideal düzeyde algılanıp ifade edilmesinde bireysel çalışmaların yapıldığı çevredeki kültürün etkisini de göstermektedir. Hem örgütsel özdeşleşme hem de dönüşümcü lidelik ve etkileşimci liderlik ölçeklerindeki bu farklılaşmayı, Triandis'in (1996) ölçekler her ne kadar uygulanacak dile çok iyi bir şekilde çevrilmiş olsalar da ele alınan kavramların farklı bir kültürde taşıdığı anlamı tam manasıyla ifade edememeleri olasıdır açıklamasıyla anlatmak mümkündür. Bu durumda, üç farklı türde ölçeğin tercih edildiği dönüşümcü liderlik ile iki farklı tür farklı türde ölçeğin tercih edildiği etkileşimci liderliğin katılımcılar tarafından farklı şekillerde algılanarak sonuçlara yansımasıyla dönüşümcü liderlik ölçeklerindekiyle benzer şekilde etkileşimci liderlik ölçeklerinin de moderatör etki oluşturmadığı anlaşılmaktadır. Nitekim bu meta-analize dahil edilmiş olan bireysel çalışmaların Türkiye'nin farklı coğrafyalarındaki İstanbul, İzmir, Bodrum, Bolu, Antalya, Sakarya, Kars, Aydın ve Adana gibi çeşitli şehirlerinde farklı büyüklüklere sahip örgütlerdeki çalışanlara uygulandıkları da açıktır. Bu durumda da gerek liderliği gerekse bu iki liderlik türünü anlamlandırarak yorumlamak pek tabi farklılık oluşturacaktır. Kullanılan örgütsel özdeşleşme ölçeklerinde ise her iki liderlik türünde de 17 çalışmanın 14'ünde Mael ve Ashforth'un (1992) geliştirdiği örgütsel özdeşleşme ölçeği tercih edilmiştir. Bu ölçeğin, örgütsel özdeşleşmeyi ölçmek üzere Cheney (1983) ve Van Dick, Wagner, Stellmacher ve Christ (2004) tarafından geliştirilmiş olan diğer ölçeklere nazaran daha kısa formda (altı ifadeli) ve yalnızca tek boyutlu olmasının uygulamada sağladığı kolaylık bakımından araştırmacıların tercih sebebi olabileceği düşünülmektedir. Dönüşümcü liderlik ile örgütsel özdeşleşme arasındaki ilişkileri ele alan çalışmalarda kullanılan örgütsel özdeşleşme ölçeğinden kaynaklanan farklılığının istatistiki anlamlılık $\mathrm{Q}_{b}$ değerinin (0.506) kritik değerin oldukça altında olduğu bulgulanırken benzer sonuç etkileşimci liderlik ile örgütsel özdeşleşme arasındaki ilişkileri ele alan altı bireysel çalışmada da elde edilmiştir. Moderatör etkinin görülmediği bir başka alt grup ise araştırmaların yürütülmüş olduğu sektördür. Oysaki araştırmaların yürütüldüğü sektöre bağlı olarak yaşanan durumlar, çalışma koşulları farkl11ık göstermektedir. Örneğin, özel sektörde kamu sektöründen farklı olarak çalışanlara sunduğu çeşitli imkanların (bireysel ve profesyonel gelişimi, eğitimler, vb.) olduğu çok açıktır. Öte yandan kamu sektöründe de iş güvencesinin devlet tarafından sağlanıyor olması söz konusudur. Ekonomik kriz ya da durgunluk yaşanması halinde devletin garantör yaklaşımı çalışana güven vermekte olup örgütünü sahiplenmesinde de etki oluşturmaktadır. Bu farklılığın da çalışanların liderlik algılamaları ve buna bağlı olarak da örgütleriyle özdeşleşmelerine de etkisi olacağı bilinmektedir (Markovits, Davis, Fay ve VanDick, 2010).

Neredeyse her bilimsel çalışmada karşılaşıldığı gibi bu meta-analiz çalışmasında da karşılaşılan bazı kısıtlar söz konusudur. Bunlardan biri, yazarların ulaşabildiği bireysel çalışmaların meta-analize dahil edilmiş olmasıdır. Bireysel araştırmacıların lisansüstü çalışmalarının hepsine ulaşılmış olsa da hakemli bilimsel dergilerin yayın politikaları gereğince makalelerin kabul edilme ve yayınlama tarihlerinin farklılık gösteriyor olması nedeniyle makalelerin sadece yayımlanmış ve okurların erişimine açılmış olanlarına ulaşılabilmiştir. Tarama yapılan arama motorları ve veri tabanları yardımıyla elde edilen bireysel çalışmalar için zengin bir anahtar kelime havuzu oluşturulmuş olsa da yapılan arama sonucunda gösterilmemiş olan ya da ulaşılamayan çalışmaların da meta-analiz çalışmasına alınamaması önemli bir başka kısıt olarak görülmektedir. Bunlara ilave olarak, meta-analize dahil edilmiş olan bireysel çalışmaların sağlamış olduğu bilgilere bağlı kalınarak örgütsel özdeşleşme için sadece örgütle yaşanan özdeşleşme kabul edilmiş olup; Van Dick vd. (2004) ele aldığ gibi alt boyutları olan bir örgütsel özdeşleşme boyutlandırılmasına gidilememiştir. Benzer nitelikte bir kısıt olarak her iki liderlik 
için de araştırmacıların boyutlarla örgütsel özdeşleşmenin ilişkisini sunan sonuçları çalışmalarında belirtmedikleri için sınıflandırmalar yapılmamıştır. Belirtilen bu kısıtlar üzerinde durularak; ilerde yapılacak olan meta-analiz çalışmalarında kullanılacak olan bireysel çalışmaların verdiği imkânlara bağl1 olarak gerek örgütsel özdeşleşme gerekse dönüşümcü liderlik ve etkileşimci liderliğin incelenmesinde boyutlara göre de çalışmaların yapılmasıyla bu meta-analiz çalışmasının ulaştığı sonuçlarla karşılaştırma yapabilmek mümkün olabilecektir.

Yapılan bu meta-analiz çalışmasında da görüldüğü gibi liderlik yalnızca sosyal yaşamın değil çalışma yaşamının da önemli bir unsurudur. Liderliğin örgütteki yansımaları ise normal şartlar altında pozitif yönde seyretmektedir. Hem dönüşümcü liderliğin hem etkileşimci liderliğin hem de örgütsel özdeşleşmenin yönetim alanında önemli birer kavram oluşu, aralarındaki ilişkinin sıklıkla ele alınıyor olmasına da zemin hazırlamaktadır. Şimdiye kadar da kadar bu ilişkiler bağlamında çok sayıda yüksek lisans ve doktora teziyle makaleler olmak üzere çeşitli yayın türlerinde görgül bireysel çalışmalar yapılmıştır. Ancak yapılmış olan bireysel çalışmaların tekrar analize alınması olan meta-analiz çalışması ilk defa yapılarak araştırma sonuçları özetlenmiştir. Yapılan bu kapsamlı analizle ulusal yazındaki bireysel çalışmalardan ulaşılmış söz konusu ilişkilerin sonuçları net olarak ifade edilerek araştırmacılara uluslararası yazında yapılmış olan bireysel çalışmaların sonuçlarıyla kıyaslama firsatı da sunması mümkün olmuştur. Böylece, Türkiye yönetim ve organizasyon ile örgütsel davranış yazınına nacizane bir katkı verilebilineceğinden söz edilmesi de mümkündür. Bu çalışmanın gelecekte dönüşümcü liderlik ve etkileşimci liderlik ile örgütsel özdeşleşme arasındaki ilişkiyi konu alarak çalışmalar yapacak olan bireysel araştırmacılar için derlenmiş, bir araya getirilmiş ve bütünlük içinde oldukça kapsamlı bir bakış açısı sağlaması ümit edilmektedir. Ayrıca, daha sonra yapılacak olan meta-analiz çalışmalarına temel teşkil etmesi ve kurama da katkı sunması beklenmektedir.

\section{Yazarların Katkı Oranı}

Çalışma tek yazarlı olduğu için yazarın katkı oranı \%100'dür.

\section{Çıkar Çatışması}

$\mathrm{Bu}$ çalışmada çıkar çatışması teşkil edebilecek bir durum yoktur.

Açıklamalar: Bu çalışma, Gebze Teknik Üniversitesi Sosyal Bilimler Enstitüsü İşletme ABD'de Prof. Dr. Oya ERDİL danışmanlığında yürütülen ve Seval AKSOY KÜRÜ'nün 2020 yılında savunduğu Örgütsel Özdeşleşmenin Öncülleri ve Ardılları Üzerine Bir Meta-Analiz Çalışması başlıklı doktora tezinin bir bölümünü temsil etmektedir.

\section{Kaynaklar}

Alagöz, M. (2019). Dönüşümcü liderlik anlayışı ile örgütsel sinizm ve örgütsel özdeşleşme ilişkisi: Bir araştırma. Yüksek Lisans Tezi, Kafkas Üniversitesi, Sosyal Bilimler Enstitüsü, Kars.

Ashforth, B. E. and Mael, F. (1989). Social identity theory and the organization. Academy of Management Review, 14(1), 20-39.

Aşık, Z. ve Özen, M. (2019). Meta-Analiz basamakları ve raporlanması. The Turkish Journal of Family Medicine and Primary Care (TJFMPC),13(2), 232-240.

Avolio, B., Bass, B.M. and Jung, D.I. (1999). Re-Examining the components of transformational and transactional leadership using the multifactor leadership questionnaire. Journal of Occupational and Organizational Psychology, 72, 441-462.

Avolio, B. J. and Gibbons, T. C. (1998). Developing transformational leaders: A lifespan approach. J. A., Conger ve R. N., Kanungo (Ed.), Charismatic leadership: The elusive factor in organizational effectiveness (pp. 276-308). San Francisco, CA: Jossey-Bass. 
Bass, B. M. and Avolio, B. J. (1992). Developing transformational leadership: 1992 and beyond. Journal of European Industrial Training, 14(5), 21-37. http://dx.doi.org/10.1108/03090599010135122.

Bass, B. M. (1999). Two decades of research and development in transformational Leadership. European Journal of Work and Organizational Psychology, 8(1), 9-32.

Begg, C. B. and Mazumdar, M. (1994). Operating characteristics of a rank correlation test for publication bias. Biometrics, 50, 1088-1101.

Black, J. S. and Porter, L. W. (2000) Management: Meeting new challenges. New Jersey: Prentice-Hall.

Bolat, O. İ. (2011). Öz yeterlilik ve lider üye etkileşimi ilişkisi: Göze girme davranışları ve güç mesafesi. Ankara: Detay Yayınc1lı.

Bottery, M. (2001). Globalisation and the UK competition state: No room for transformational leadership in education. School Leadership and Management, 21(2), 199-218.

Bryman, A. (1992). Charisma and leadership in organizations. London: Sage Publications.

Burns, J. M. (1978). Leadership. New York: Harper\&Row Publishing.

Coad, A. F. and Berry, A. J. (1998). Transformational leadership and learning orientation. Leadership and Organization Development Journal, 19(3), 164-172.

Cohen, L., Manion, L. and Morrison, K. (2007). Research methods in education (6th ed.). New York, US: Routledge/Taylor \& Francis Group.

Çeri Booms, M. (2009). An empirical study on transactional, transformational and authentic leaders: Exploring the mediating role of "trust in leader" on organizational identification. Doktora Tezi, Yeditepe üniversitesi, Sosyal Bilimler Enstitüsü, İstanbul.

Çulhaoğlu Uludağ, C. (2015). Özdeşleşme, liderlik tarzları ve kültürel faktörler arasındaki ilişsi. Doktora Tezi, Beykent Üniversitesi, Sosyal Bilimler Enstitüsü, İstanbul.

Demir, H. ve Okan, T. (2008). Etkileşimsel ve dönüşümsel liderlik: Bir ölçek geliştirme denemesi. İstanbul İktisadı Enstitüsü Dergisi, 61, 72-90.

Dickersin, K., Min, Y.I. and Meinert, C. L. (1992). Factors influencing publication of research results: Follow-up of application submitted to two institutional review boards. Jama, 267(3), 374-378.

Doğanl, U. (2019). Dönüşümcü liderlik ve örgütsel özdeşleşme ilişkisinde örgüt kültürünün düzenleyici etkisine yönelik bir araştırma. Yüksek Lisans Tezi, Balıkesir Üniversitesi, Sosyal Bilimler Enstitüsü, Balıkesir.

Downton, J. V. (1973). Rebel leadership: Commitment and charisma in the revolutionary process. New York: Free Press.

Dubrin, A. J. (2010). Principles of leadership (6th ed.). Sydney: South-Western.

Dutton, J. E., Dukerich J. M. and Harquail, C. V. (1994). Organizational images and membership commitment. Administrative Science Quarterly, 34, 191-206.

Egger, M., Smith, G. D., Schneider, M. and Minder, C. (1997). Bias in meta-analysis detected by a simple, graphical test. British Medical Journal, 315(7109), 629. 
Epitropaki, O. and Martin, R. (2005). The moderating role of individual differences in the relation between transformational/transactional leadership perceptions and organizational identification. The Leadership Quarterly, 16(4), 569-589.

Erdoğan Morçin, S. ve Morçin, İ. (2013). Etkileşimci liderliğin örgütsel özdeşleşmeye etkisi: Adana'daki seyahat acenteleri örneği. İsletme Araştırmaları Dergisi, 5(4), 71-86.

Erdoğan Morçin, S. ve Çarıkçı, İ. H. (2016). Dönüşümcü/Etkileşimci liderliğin iş tatminine etkisinde örgütsel özdeşleşmenin aracılık rolü: Antalya'daki beş yıldızlı otel işletmeleri örneği. Süleyman Demirel Üniversitesi Iktisadi ve İdari Bilimler Fakültesi Dergisi, 21(1), 97-112.

Eren, M. Ş. ve Çakır Titizoğlu, Ö. (2014). Dönüşümcü ve etkileşimci liderlik tarzlarının örgütsel özdeşleşme ve iş tatmini üzerindeki etkileri. Selçuk Üniversitesi İktisadi ve İdari Bilimler Fakültesi Sosyal ve Ekonomik Araştırmalar Dergisi, 14(27), 275-303.

Field, A. P. and Gillett, R. (2010). How to do a meta-analysis. British Journal of Mathematical \& Statistical Psychology, 63(3), 665-694.

Geijesel, F., Sleegers, P. and VanDen Berg, R. (1999). Transformational leadership and the implementation of large scale innovation programs. Journal of Educational Administration, 37(4), 309-328.

Gomes, A. R. (2014). Transformational leadership: Theory, research, and application to sports. Mohiyeddini, C. (Ed.), Contemporary topics and trends in the psychology of sports (pp. 53114). New York: Nova Science Publishers.

Greenberg, J. and Baron, R. A. (2000). Behaviour in organizations (7th Ed.). New Jersey: Prentice-Hall.

Güngör, H. (2010). Dönüşümcü liderlik ile örgütsel özdeşleş̧me arasindaki ilişkinin incelenmesi: Algllanan örgütsel adalet düzeyinin aracıllk etkisi. Yüksek Lisans Tezi, Kara Harp Okulu Savunma Bilimleri Enstitüsü, Ankara.

İşcan, Ö. F. (2006). Dönüşümcü/Etkileşimci liderlik algııı ve örgütsel özdeşleşme ilişkisinde bireysel farklılıkların rolü. Akdeniz Üniversitesi I.I.̇.B.F. Dergisi, 6(11), 160-177.

Jung, D. I. and Avolio, B. J. (1999). Effects of leadership style and followers cultural orientation on performance in group and individual task conditions. Academy of Management Journal, 42(2), 208-218.

Karsl1, E. (2019). Dönüşümcü liderliğin motivasyon ve örgütsel özdeşleşmeye etkisi. Yüksek Lisans Tezi, Sakarya Üniversitesi, Sosyal Bilimler Enstitüsü, Sakarya.

Macit, M. (2003). Leadership and bass transactional and transformational leadership theory. SÜ İIBF Sosyal ve Ekonomik Araştırmalar Dergisi, 3(5),86-114.

Markovits, Y., Davis, A. J., Fay, D. and VanDick, R. (2010). The link between job satisfaction and organizational commitment: Differences between public and private sector employees. International Public Management Journal, 13(2), 177-196.

Nielsen, K. and Cleal B. (2011). Under which conditions do middle managers exhibit transformational leadership behaviours'. The Leadership Quarterly, 22, 344-352.

Odumeru, J. A. and Ifeanyi, G. O. (2013). Transformational vs. transactional leadership theories: evidence in literature. International Review of Management and Business Research, 2(2), 355- 
361.

Özsöylemez, O. (2009). Algılanan liderlik tarzlarının iş tatmini ve işten ayrlma niyeti üzerindeki etkisinde örgütle özdeşleşmenin rolü. Yüksek Lisans Tezi, Marmara Üniversitesi, Sosyal Bilimler Enstitüsü, İşletme Anabilim Dalı, İstanbul.

Patchen, M. (1970). Participation, achievement and involvement on the job. New Jersey: Prentice- Hall.

Pillai, R., Schriesheim, C. A. and Williams, E. S. (1999). Fairness perceptions and trust mediators for transformational and transactional leadership: A two sample study. Journal of Management, 25(6), 897-933.

Podsakoff, P. M., Mackanzie, S. B., Moorman, R. H. and Fetter, R. (1990). Transformational leader behaviours and their effects on followers' trust in leader, satisfaction, and organizational citizenship behaviours. Leadership Quarterly, 1(2), 107-142.

Shriberg, A., Shriberg, D. L. and Lloyd, C. (2002) Practicing leadership: Principles and applications. New York: John Wiley\&Sons, Inc.

Tajfel, H. (1978). Social categorization, social identity, and social comparison. Tajfel, H. (Ed.), Differantiation between social groups: Studies in the social psychology of intergroup relations (pp. 61-76). London: Academic Press.

Tajfel, H. and Turner, J. C. (1986). The social identity theory of intergroup behaviour. Worchel, S. ve Austin, W. G. (Ed.), Psychology of intergroup relations (pp. 7-24). Chicago, IL, Nelson.

Temel, E. (2016). Dönüşümcü liderlik ve psikolojik güçlendirme arasındaki ilişkide örgütsel özdeşleşmenin aracıllk rolü: Nazilli'deki kamu kurumlarında bir uygulama. Yüksek Lisans Tezi, Adnan Menderes Üniversitesi, Sosyal Bilimler Enstitüsü, Aydın.

Van Dick, R., Wagner, U., Stellmacher, J. and Christ, O. (2004). The utility of a broader conceptualization of organizational identification: Which aspects really matter? Journal of Occupational and Organizational Psychology, 77, 171-191. 


\section{Extended Abstract}

\section{Introduction}

It is a desired situation for employees, who are the most valuable capital for organizations, to be in unity with their organizations. Sometimes this can be done by the employee's own effort; sometimes it requires the presence of a leader who can guide the employee. Transformational leadership and interactive leadership are also a precursor to organizational identification. In the literature, it has been concluded that transformative leadership from Social Identity Theory to organizational identification has positive effects (Avolio and Gibbons 1998; Epitropaki and Martin, 2005). It is known that interactionist leadership has a positive relationship with organizational identification, such as transformative leadership (Pillai, Schriesheim and Williams, 1999). When the literature is analyzed, it is seen that there is no meta-analysis examining the relationship between these two types of leadership and organizational identification. The main purpose of the research is to determine whether transformative leadership and interactive leadership are related to organizational identification.

\section{Method}

According to Hunter and Schmidt (2004), meta-analysis is more comprehensive than review and re-examination studies. In other words, it gives the opportunity to gather and summarize the results of individual studies quantitatively by giving the relationships between the variables considered as close to reality as possible. Meta-analysis method was used to calculate the total effect size of the results of individual studies. The universe and sample of the research consist of individual studies that consider the Turkish sample and evaluate the relationships between transformational leadership and transactional leadership and organizational identification. Since there is no meta-analysis study on the relationship of transformational leadership and interactionist leadership with organizational identification, all studies in the national literature, including December 2019, have been discussed. For the literature review; Council of Higher Education (CoHE) National Thesis Center, Turkish Academic Network and Information Center (Ulakbim), Dergipark, ERIC, DOAJ, PsycINFO, Sage Journals Online, Science Direct, Springer Link, Taylor and Francis Online Journals, Wiley Online Library databases were used. In addition, internet search engines (Google Scholar, Yandex and Google) were also scanned. Organizational identification, organizational identification, organizational identification, organizational identification, organizational identity, organizational identification, organizational identification, organizational idendity, oi, öö, org. özd., transformational leadership and interactive leadership keywords are used. In the inclusion of these studies in the analysis, some criteria were considered as listed below.

- Individual studies to be included in the meta-analysis have addressed the relationship between organizational identification and transformational leadership and/or transactional leadership. Examining the Turkish sample of the individual study that dealt with the relationship between organizational identification and transformational leadership and/or transactional leadership,

- Individual studies made on the subject must be empirical studies. Each of the individual studies that have addressed the relationship between organizational identification and transformational leadership and/or transactional leadership has undergone a rigorous and objective peer review,

- These individual studies include the correlation coefficient or values (t-test and F-test) that help in calculating the correlation coefficient in the findings and results revealed regarding the evaluation of this relationship.

The criteria for not being included in the meta-analysis are as follows.

- Abstracts other than graduate studies and articles are not included in the meta-analysis study because they are not subject to a qualified and objective peer review,

In the event that individual researchers have conducted more than one study using the same sample, only one of these individual studies, even if they were conducted in different years, is included in the meta-analysis. The Turkish version of the PRISMA flowchart used for the systematic review and 
meta-analysis, including all these criteria and the steps followed, is given in Figure 1 (Aşık and Özen, 2019). Within the scope of the research, 19 individual studies were reached. With the detailed examination conducted, 17 studies were included in the meta-analysis which included the correlation value, which is the basic criterion of being included in the meta-analysis.

\section{Findings}

Pearson correlation coefficient was used to calculate the effect size in the relationship between transformative leadership and organizational identification, and in the relationship between interactive leadership and organizational identification. Effect size values, 95\% confidence interval values and Fisher $\mathrm{Z}$ values, which are calculated according to fixed and random effect models, were examined. Random effect models were used for both types of leadership. In the relationship between transformational leadership and organizational identification, the effect size $r=0.386$ was calculated. In the relationship between transactional leadership and organizational identification it is calculated as $\mathrm{r}=0.347$. It was found that there was no publication bias and no moderator effect on the relationship between both leadership types and organizational identification.

\section{Results, Discussion and Suggestions}

Firstly, the results of 11 individual studies dealing with the relationship between transformative leadership and organizational identification were analyzed and the overall effect size was calculated as $\mathrm{r}=0.386, \mathrm{p}<0.005$. Transformational leadership ensures that employees adopt the values of the organization and provide them with unity and integrity, thus enabling employees to participate and establish identification with their organizations, thereby transforming their potential into performance (Bryman, 1992). It is clear that employees identified with organizational goals also adopt important behavior patterns of their leaders. Thus, the behavior of the leader creates a role model and creates a positive effect for organizational identification (Podsakoff, Mackanzie, Moorman, and Fetter, 1990). Thus, the first sub-problem was answered by the parallel with the literature. In addition, the lower and upper limits of the effect size values of 11 studies were found to be $0.313-0.458$, respectively. The effect size value was calculated as $\mathrm{r}=0.347, \mathrm{p}<0.005$, by performing the same procedure for 6 individual studies that deal with the relationship between interactive leadership and organizational identification. In studies that found that the interactionist leadership examined with frequent transformative leadership is in relation to organizational identification, where the leader explicitly puts his employees' gains in meeting the expectations of the employees and if they are obeyed by loyalty to the leader (Pillai, Schriesheim and Williams, 1999). Thus, with this interaction and effective communication, employees are made to feel like a part of their organizations. Thus, employees also work in a small community, feeling uncertain and safe (Geijesel, Sleegers and VanDen Berg, 1999). Thus, the third sub-problem was answered. It is understood that in the relationship of these two types of leadership with organizational identification, the effect size values remain close to each other.

With this comprehensive analysis, the results of the said relations, which have been obtained from the individual studies in the national literature, have been clearly expressed and have been able to offer researchers the opportunity to compare the results of individual studies conducted in the international literature. Thus, it is possible to mention that a modest contribution can be made to the Turkish administration and organization and organizational behavior literature. It is hoped that this study will compile, gather, and provide a comprehensive perspective in integrity, which will be compiled for individual researchers who will conduct studies on the relationship between transformative leadership and interactive leadership and organizational identification in the future. It is also expected to serve as a basis for meta-analysis and to contribute to the theory. 